Review Article

\title{
Nutritive Importance and Therapeutics Uses of Three Different Varieties (Murraya koenigii, Micromelum minutum, and Clausena indica) of Curry Leaves: An Updated Review
}

\author{
D. T. Abeysinghe ${ }^{D},{ }^{1}$ D. D. D. H. Alwis ${ }^{\circ},{ }^{1}$ K. A. H. Kumara ${ }^{\circ},{ }^{1}$ and U. G. Chandrika ${ }^{2}$ \\ ${ }^{1}$ Department of Chemistry, Faculty of Natural Sciences, The Open University of Sri Lanka, Nawala, Nugegoda, Sri Lanka \\ ${ }^{2}$ Department of Biochemistry, University of Sri Jayewardenepura, Nugegoda, Sri Lanka \\ Correspondence should be addressed to D. T. Abeysinghe; dtabe@ou.ac.lk
}

Received 6 January 2021; Revised 1 June 2021; Accepted 8 October 2021; Published 31 October 2021

Academic Editor: Saheed Sabiu

Copyright (c) 2021 D. T. Abeysinghe et al. This is an open access article distributed under the Creative Commons Attribution License, which permits unrestricted use, distribution, and reproduction in any medium, provided the original work is properly cited.

\begin{abstract}
Murraya koenigii (M. koenigii), Micromelum minutum (M. minutum), and Clausena indica (C. indica) are three varieties of curry leaves in the family Rutaceae. They have been widely used in Ayurvedic medicine worldwide in the treatment and prevention of various diseases. Earlier findings provide strong evidence to support the three curry leaf species' potent pharmaceutical and biological effects, including antioxidant, antidiabetic, anti-inflammatory, and antitumor activities. Various parts of these plants, such as leaves, seeds, flowers, and fruit, contain constituents responsible for the modulation of numerous biological processes. Leading constituents of curry leaves play a crucial role in diabetic and anticancer management by regulating various molecular pathways, including Bcl-2, Bax, NF- $\kappa \mathrm{B}$, and TNF $\alpha$, according to in vitro and in vivo models established. Therefore, this review summarizes the current knowledge on research achievements made in terms of phytoconstituents, their structures, biological activities, and pharmacological actions with clinical studies of curry leaves up to date. The review also emphasizes the necessity for comprehensive research studies on the pharmacological actions and the mechanisms of selected phytochemicals of $M$. koenigii, M. minutum, and C. indica to validate their efficacy as potent herbal remedies for many ailments.
\end{abstract}

\section{Introduction}

The use of plant-based natural products in the treatment and prevention of diseases and health enhancement due to nutritive importance and pharmacological benefits has led to the significant attention of the scientific community and the general public nowadays. Medicinal plants are readily available and provide a cost-effective source with lesser side effects to develop new drugs $[1,2]$. Plant-based traditional medicine is the stronghold of societies of many Asian countries in dealing with health and has a long history since ancient civilization, which uses plant materials as a significant ingredient in synthesizing drugs in different forms such as decoctions. It is a widely accepted fact that the rapid development of deriving pharmacologically active drugs from medicinal herbs has a tremendous impact on current medicinal practices [3]. For instance, in cancer treatment, more than $60 \%$ of all pharmaceuticals on the current market are natural products or mimics of natural products [4]. Furthermore, research has showed that plant-based diets rich with medicinal herbs are low-risk interventions that lower body mass index (BMI), blood pressure, glycated hemoglobin (HbA1C), and cholesterol levels. Therapeutic herbs may also reduce the number of medications needed to treat many metabolic and noncommunicable diseases, including diabetes, cancers, cardiovascular diseases, obesity, and the majority of metabolic and noncommunicable diseases are linked with higher mortality and morbidity rates [5]. Curry leaves are the most common herb used in Asia with enormous nutritive and pharmacological benefits. Therefore, this review is mainly focused on the phytochemical constituents and their bioactivities in three 
different varieties of curry leaves, Murraya koenigii (M. koenigii), Micromelum minutum (M. minutum), and Clausena indica (C. indica) available in most Asian countries. Their phytochemical constituents play a role in disease management through the managing of many metabolic pathways.

Rutaceae, the family of flowering plants, is composed of 160 genera and a few herbaceous perennials [6]. Of the 2070 global species belonging to the family Rutaceae, only a few herbaceous varieties are available in Sri Lanka, including $M$. koenigii, M. minutum, and C. indica. Of the three, M. koenigii is a fascinating house plant grown in Asia and native to Sri Lanka, Bangladesh, and India, which had used curry leaves or "karapincha" (in Sinhala) for centuries. The dark green fresh leaflets of $M$. koenigii are widely used in Asian cooking mainly for their aroma and versatile medicinal properties $[7,8]$. Furthermore, they add subtle flavors to various food preparations, from vegetables to many other dishes as a natural flavor. Kola kanda or leafy porridge is famous in Sri Lanka for its high nutritional value. Various parts of M. koenigii are used to treat diabetes, chronic fever, dysentery, and diarrhea [9]. M. minutum is also used as a flavoring agent and is reported to have medicinal value in the southern part of Thailand and many other Asian countries [10]. In particular, M. minutum roots are used to cure ringworms and to regulate menstruation. Other parts of $M$. minutum are used as carminatives, purgatives, and expectorants $[11,12]$. The leaves of $M$. minutum are used traditionally to treat toothache and teething issues in babies, skin irritations caused by scabies, and as a remedy for stomachache and headache [13]. C. indica is famous as a folk medicine in many Asian countries. Leaves and roots of C. indica treat various health issues, such as flu, colds, joint dislocation, bone fractures, headaches, colic, and rheumatism. Moreover, C. indica fruits are widely used in Vietnam and South Indian cooking mainly due to their aroma $[14,15]$. The three varieties of curry leaf, M. koenigii, M. minutum, and C. indica discussed in the review, have somewhat common morphological characteristics and taxonomic positions as indicated in Table 1. Morphologies of the leaves and fruits of M. koenigii, M. minutum, C. indica are shown in Figure 1.

\section{Beneficial Pharmacological Activities of M. koenigii, M. minutum, and C. indica and Their Isolated Constituents}

In the recent past, the use of M. koenigii and M. minutum in traditional medicines and home remedies has attracted the scientific community, but limited studies have been conducted to evaluate their pharmacological and medicinal efficacy. Despite the importance of $C$. indica in folkloric remedies, its pharmacological potential and chemical constituents have been rarely identified. Therefore, this review will shed light on the major bioactive compounds of M. koenigii, M. minutum, and C. indica and their pharmacological effects highlighting the potential in the key medicinal activities through the modulation of various biological pathways. The major pharmacological activities of the M. koenigii, M. minutum, and C. indica are discussed in detail in this review (Figure 2).

Several studies have contributed to understanding the chemical constituents and therapeutic actions of $M$. koenigii, $M$. minutum, and $C$. indica. Their bioactive compounds have been extracted from various solvents (water, hexane, dichloromethane, methanol, ethyl acetate, and benzene) and have been thoroughly explored using different techniques, including mass spectrometry, Nuclear Magnetic Resonance Spectroscopy (NMR), Infrared, and ultraviolet spectroscopy. Alongside these studies, pharmacological activities of the isolated compounds have been carried out via in vitro and in vivo studies combined with animal models.

Tables 2-4 summarize the major chemical constituents of $M$. koenigii, $M$. minutum, and $C$. indica and their pharmacological activities. All three varieties have nutritive value owing to the presence of a variety of essential phytochemicals, minerals, and trace minerals present primarily in their leaves and seeds. Phytochemical studies of the leaves, roots, seeds, and stem bark of M. koenigii, M. minutum, and $C$. indica have yielded many essential metabolites such as terpenoids, polyphenols, coumarins, alkaloids, flavonoids, carotenoids, vitamins, and nicotinic acid, as summarized in the supplementary information Tables S1-S3.

The three species selected in this review, M. koenigii, $M$. minutum, and $C$. indica, have demonstrated a wide range of common pharmacological effects such as antihyperlipidemic, antimicrobial, antioxidant, and antihyperglycemic, and apoptotic activities [19, 32-35]. The two species, M. koenigii and M. minutum, have demonstrated remarkable cytotoxic anticarcinogenic activities. In addition, M. minutum has shown a remarkable effect as a poultice for ringworms [35]. M. koenigii, M. minutum, and C. indica contain various phytoconstituents that play an essential role in disease management via modulation of different cell signaling pathways (Figure 3).

2.1. Antihyperglycemic Activities. Diabetes mellitus is a deeprooted disorder because the body cannot maintain blood glucose levels and needs long-term/lifetime medication [36]. Hyperglycemia or high blood glucose is a symptom of diabetes mellitus. In 1995, the estimated prevalence of diabetes among adults was $4 \%$, and specialists predict that it will rise to $5.4 \%$ in 2025 [37]. For the management of diabetes mellitus, a particular remedy must have excellent glycemic control activity. If diabetes is left untreated, there is a possibility of degeneration even from its primary stages. It is associated with multiple disorders such as chronic hyperglycemia, weak carbohydrate, protein, and fat metabolism resulting from imperfections in insulin secretion. It was also found that life pattern changes can affect diabetes with considerable subsequent complications [36].

Etiologies of diabetes are highly variable. Two significant forms of diabetes exist, commonly referred to as type 1 and type 2. Among them, type 1 is recorded as a T cell-mediated autoimmune disease. The latter (type 2) diabetes is reported as $90 \%$ of the diabetes population in the world, being the 
TABLE 1: Morphological parameters and taxonomic positions of M. koenigii, M. minutum, and C. indica.

\begin{tabular}{|c|c|c|c|}
\hline $\begin{array}{l}\text { Morphological } \\
\text { parameters }\end{array}$ & M. koenigii & M. minutum & C. indica \\
\hline Tree & $\begin{array}{l}\text { Shrub or tree } 6 \mathrm{~m} \text { in height and } 15-40 \mathrm{~cm} \text { in } \\
\text { diameter of the trunk }\end{array}$ & Shrub to small tree to $9 \mathrm{~m}$ high & Shrub to small tree \\
\hline Bark & $\begin{array}{l}\text { Grey color bark with longitudinal striations } \\
\text { and white bark is present beneath it }\end{array}$ & Grayish brown bark & $\begin{array}{l}\text { Grayish bark with scattered round } \\
\text { glands to } 0.35 \mathrm{~mm} \text { diameter }\end{array}$ \\
\hline Leaf & $\begin{array}{l}\text { Leaves are bipinnately compound, } \\
15-30 \mathrm{~cm} \text { long, bearing } 11-25 \text { leaflets } \\
\text { alternate on rachis, irregular margins }\end{array}$ & $\begin{array}{l}\text { Leaves are pinnate with } 7-15 \text { leaflets. } \\
\text { Each leaflet is } 2-10 \mathrm{~cm} \text { long, } 1-6 \mathrm{~cm} \\
\text { broad }\end{array}$ & $\begin{array}{l}\text { Compound, exstipulate, } \\
\text { imparipinnate, large, } 1-30 \mathrm{~cm} \\
\text { long; leaflets } 7-13 \text {, shortly stalked, } \\
3.7-8 \mathrm{~cm} \text { long, unequal at base }\end{array}$ \\
\hline Flowers & $\begin{array}{l}\text { Bisexual, white, sweetly scented, stalked } \\
\text { funnel-shaped, complete, diameter } 1.12 \mathrm{~cm} \\
\text { terminal cymes each bearing 60-90 flowers }\end{array}$ & $\begin{array}{c}\text { Petals are valvate. Cotyledons } \\
\text { crumpled; style as long as ovary and } \\
\text { white flowers in mostly flat-topped } \\
\text { corymbose cymes }\end{array}$ & $\begin{array}{l}\text { Inflorescence racemose } \\
\text {-paniculate with greenish-white } \\
\text { flowers, } 6-8 \mathrm{~mm} \text { long. Style } \\
\text { shorter than the ovary }\end{array}$ \\
\hline Fruits & $\begin{array}{c}\text { Ovoid to subglobose, wrinkled, or rough } \\
\text { with glands; } 2.5 \mathrm{~cm} \text { long and } 0.3 \mathrm{~cm} \text { in } \\
\text { diameter purplish-black color when ripen; } \\
\text { biseeded }\end{array}$ & $\begin{array}{l}\text { Young fruits green, ellipsoid, and } \\
\text { oblong, scented. A ripe fruit grows } \\
\text { up to } 5-9 \mathrm{~mm} \text { long and appears in } \\
\text { yellow, orange, and red color } \\
\text { according to maturity }\end{array}$ & $\begin{array}{l}\text { Globular berry, pink, or cream- } \\
\text { colored, 1-2 cm long, gland-dotted }\end{array}$ \\
\hline Seeds & $\begin{array}{l}\text { Spinach green color, } 11 \mathrm{~mm} \text { long, } 8 \mathrm{~mm} \text { in } \\
\text { diameter and weighs up to } 445 \mathrm{mg} \text { [16] }\end{array}$ & $\begin{array}{l}\text { Seeds with green and crumpled } \\
\text { cotyledons }\end{array}$ & Solitary, green color \\
\hline \multirow{10}{*}{ Taxonomy } & Kingdom Plantae & Kingdom Plantae & Kingdom Plantae \\
\hline & Subkingdom Tracheobionta & Subkingdom Tracheobionta & Subkingdom Tracheobionta \\
\hline & Superdivision Spermatophyta & Superdivision- Spermatophyta & Superdivision Spermatophyta \\
\hline & Division Magnoliophyta & Division Magnoliophyta & Division Magnoliophyta \\
\hline & Class Magnoliopsida & Class Magnoliopsida & Class Magnoliopsida \\
\hline & Subclass Rosidae & Subclass Rosidae & Subclass Rosidae \\
\hline & Order Sapindales & Order Sapindales & Order Sapindales \\
\hline & Family Rutaceae & Family Rutaceae & Family Rutaceae \\
\hline & Genus Murraya & Genus Micromelum & Genus Clausena \\
\hline & Species Murraya koenigii L. Spreng [17]. & Species Micromelum minutum [18] & Species Clausena indica [19] \\
\hline
\end{tabular}

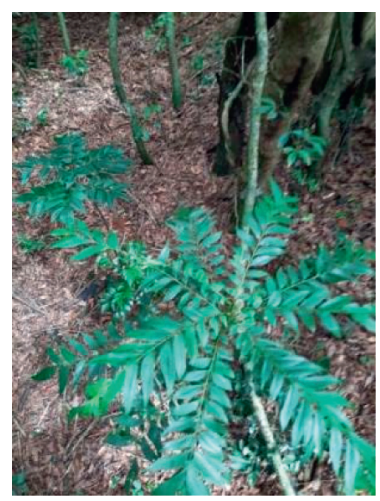

(a)

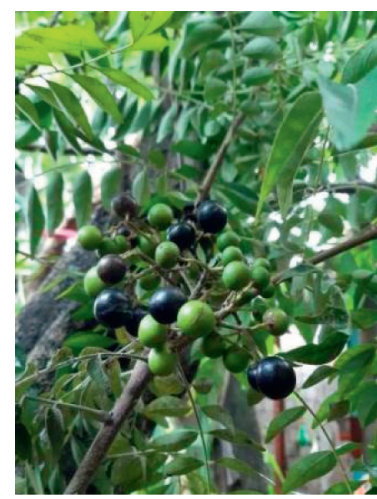

(b)

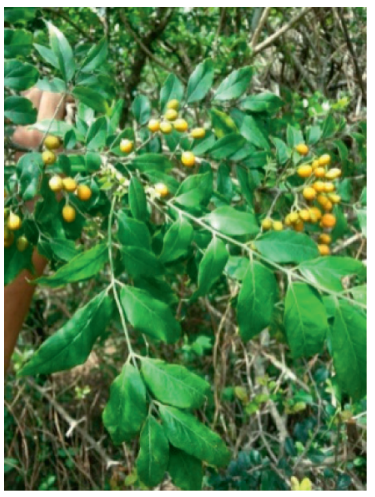

(c)

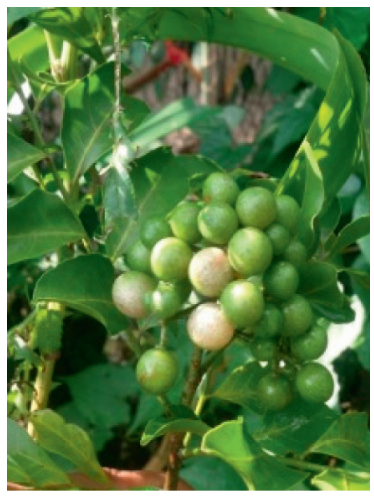

(d)

FIGURE 1: Morphologies of (a) leaves of M. koenigii, (b) fruits of M. koenigii. (c) Leaves and fruits of M. minutum. (d) Leaves and seeds of C. indica.

most prevalent form of diabetes that is referred to as noninsulin-dependent diabetes. Type 2 diabetes may be owing to obesity and unhealthy lifestyles among individuals. While insulin production is present in this form, the extent of produced insulin may be inadequate to meet the body's needs or, in some cases, may be due to insulin resistance development [36]. Recently, investigators have studied the effect of curry leaves for the treatment of diabetes as they provide an affordable source with low side effects.

In this regard, a large amount of work has been done using animal models to study the effectiveness of $M$. koenigii leaf extracts on hyperglycemic activity. Rats have been 


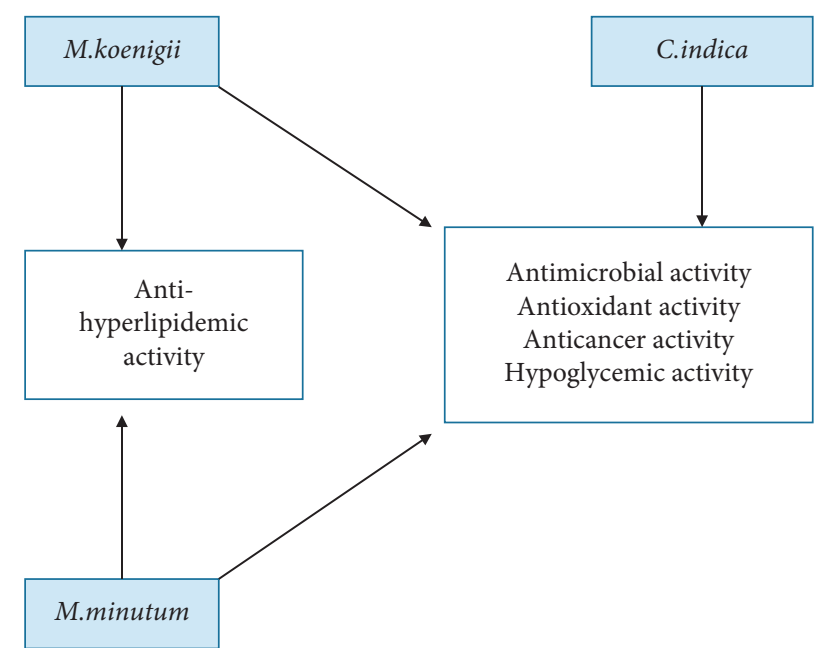

FIgURE 2: Major pharmacological activities of M. koenigii, M. minutum, and C. indica.

selected as suitable animal models after inducing diabetes with different drugs, alloxan or streptozotocin (STZ), to mimic human hypoglycemic conditions. Several studies on the antihyperglycemic activity of $M$. koenigii in various solvents with varying degrees of polarities are reported. The rationale behind using solvents of varying polarity is to search for more promising drugs to manage hypoglycemic conditions. Water is the most common solvent used because of $M$. koenigii's common use in aqueous food preparations and decoctions.

A study with alloxan-induced diabetic rats administrated with the aqueous extract of $M$. koenigii leaves demonstrated a substantial decrease in the blood glucose levels of diabetic mice. Notably, no effect on the blood glucose levels of normal treated mice was observed, and the aqueous extract exhibited a significant reduction of the blood glucose level in rats at a dose of $200 \mathrm{mg} / \mathrm{kg}$. This observation indicates a promising therapeutic effect on diabetes by $M$. koenigii with fewer or no undesirable side effects [37]. Several studies on aqueous leaf extracts are in line with this observation of the efficacy of $M$. koenigii in treating hyperglycemia [38-40].

Fresh juice of $M$. koenigii leaves has shown an effect on reduced blood glucose levels. Also, it enhances the effect of insulin by extending its therapeutic value in a study with healthy Wistar rats [41]. A successful combination of $M$. koenigii with insulin was achieved, and restoration of glucose homeostasis alone or in combination with other antihyperglycemic agents was suggested [41]. Therefore, the beneficiary effect in combination of $M$. koenigii with insulin indicates a clinical potential of developing a safe therapeutic approach to diabetic management that needs to be validated for the long run. A study was undertaken to evaluate the protective effects of $M$. koenigii leaves aqueous extract against beta-cell damage in streptozotocin-induced diabetes rats. The results showed that administration of $M$. koenigii leaves effectively brings about its antihyperglycemic effect via secretion of insulin secretion from the regenerated beta cells and remnant beta cells [40]. Another study was made to investigate the hypoglycemic activity of aqueous and methanolic M. koenigii leaves extracts on plasma insulin and blood glucose levels in alloxan-induced diabetic rats. These researchers had successfully achieved a significant reduction $(P<0.05)$ of blood glucose levels of diabetic rats treated with methanol and aqueous extracts compared to the diabetic control group. A significant rise in plasma insulin was observed on the $43^{\text {rd }}$ and $58^{\text {th }}$ days of treatment in methanol and aqueous extracts suggesting stimulated secretion of insulin from the beta cells of pancreatic cells [42]. Another study investigated the efficacy of feeding $M$. koenigii leaves as dietary constituents in controlling hyperglycemia in normal rats, alloxan- or STZ-induced mild diabetic rats, or moderate diabetic rats [43]. It was observed that the mild diabetic rats displayed a moderate antihyperglycemic activity but a poor antihyperglycemic activity was observed in moderately diabetic rats. However, the feeding of $M$. koenigii leaves did not affect any profound hypoglycemic effect in normal rats, as stated in previous findings [43]. Another study was made to evaluate the hypoglycemic effect of ethanolic leaf extracts of $M$. koenigii on alloxan-induced diabetic rats, where results revealed that the extract exhibited hypoglycemic effects [44]. Another study revealed that the chloroform extract of $M$. koenigii enhanced insulin secretion from the pancreas [45].

Raised glycated hemoglobin concentration in plasma is the clinical hallmark of poorly controlled diabetes [46]. Glycated hemoglobin is a modified hemoglobin product of a nonenzymatic condensation of glucose with hemoglobin during hyperglycemia. Therefore, glycated hemoglobin (HbA1C) contributes as a biomarker, easily indicating the management status of diabetes in patients [47]. Studies have been carried out to determine the effect of $M$. koenigii on hemoglobin glycation and alloxan-induced diabetic rats with a blood glucose level of $13 \mathrm{mmol} / \mathrm{l}$. Alloxan-induced diabetic rats were treated orally with a crude aqueous extract ( $500 \mathrm{mg} / \mathrm{kg}$ body weight), and the outcome of the study indicated a significant $(P<0.05)$ decrease in blood glucose and glycated hemoglobin levels compared to the diabetes control group [47].

Inhibition of hemoglobin glycations is considered to be one of the therapeutic approaches that delay or prevent the progression of major diabetic complications. A method was developed with bovine serum albumin (BSA) using polyacrylamide gel electrophoresis under native conditions (PAGE) to investigate the in vitro protein glycation inhibitory potential of $M$. koenigii aqueous leaf extract. The results revealed that, in the presence of $M$. koenigii aqueous leaf extract, migration of BSA under nondenaturing conditions was retarded compared to the control [48]. This work suggested an in vitro protein glycation inhibitory potential of the M. koenigii aqueous leaf extract.

Diabetic peripheral neuropathy, a peripheral nerve disorder, develops as a late manifestation of long-standing or uncontrolled diabetes. A study was made to evaluate neuropathy management in male Wistar rats by the ethanolic extract of M. koenigii leaves. The study results showed that ethanolic extract successfully regulated the blood glucose level and managed neuropathy [49]. Studies of this manner 
TABLE 2: The major bioactive compounds of M. koenigii and their pharmacological activities.

\begin{tabular}{|c|c|c|c|c|c|c|}
\hline No & Plant part & $\begin{array}{c}\text { Chemical } \\
\text { type }\end{array}$ & Chemical & Structure & Activity & Ref \\
\hline 01 & Stem & & Girinimbine & & $\begin{array}{c}\text { Antimicrobial/ } \\
\text { anticancer/antitumor }\end{array}$ & \\
\hline 02 & Leaves/stem & & Murrayanine & & $\begin{array}{c}\text { Antimicrobial/ } \\
\text { anticancer/antioxidant }\end{array}$ & \\
\hline 03 & Leaves/stem & & Mahanine & & & \\
\hline 04 & Stem/bark & Alkaloids & Murrayacine & & & \\
\hline 05 & Leaves & & Murrayanol & & $\begin{array}{l}\text { Antioxidant/anti- } \\
\text { inflammatory/ } \\
\text { antimicrobial }\end{array}$ & [20] \\
\hline 06 & Stem/bark & & Mukoeic acid & & Antioxidant & [9] \\
\hline 07 & Stem/bark & & Murrayazolinine & & Anticancer & {$[9,16,21]$} \\
\hline 08 & Roots & Alkaloids & Mukoline & & Cytotoxic/antimicrobial & {$[7,9,21]$} \\
\hline
\end{tabular}


TABle 2: Continued.

\begin{tabular}{|c|c|c|c|c|c|c|}
\hline No & Plant part & $\begin{array}{c}\text { Chemical } \\
\text { type }\end{array}$ & Chemical & Structure & Activity & Ref \\
\hline 09 & $\begin{array}{l}\text { Leaves/stem/ } \\
\text { bark }\end{array}$ & & Mahanimbine & & Antioxidant/anticancer & {$[7]$} \\
\hline 10 & Leaves/bark & Alkaloids & Koenine & & $\begin{array}{l}\text { Antioxidant/ } \\
\text { antidiarrheal }\end{array}$ & {$[9]$} \\
\hline 11 & Leaves & & Koenigine & & Antioxidant & [22] \\
\hline 12 & Stem/roots & & Koenoline & & Cytotoxic & [23] \\
\hline 13 & Leaves & & Koenimbine & & $\begin{array}{c}\text { Antioxidant/ } \\
\text { antidiarrheal/anticancer }\end{array}$ & {$[7]$} \\
\hline 14 & Roots & & $\begin{array}{l}\text { 9-Formyl-3- } \\
\text { methylcarbazole }\end{array}$ & & Anticancer & {$[7]$} \\
\hline 15 & Leaves & & $\begin{array}{l}\text { O-methylmurrayamine } \\
\text { A }\end{array}$ & & Antioxidant & {$[24]$} \\
\hline 16 & & & Linalool & & & \\
\hline 17 & Leaves & $\begin{array}{l}\text { Essential } \\
\text { oils }\end{array}$ & Elemol & & $\begin{array}{l}\text { Antioxidant/ } \\
\text { antimicrobial }\end{array}$ & {$[25]$} \\
\hline 18 & & & Geranyl acetate & & & \\
\hline 19 & & & Myrcene & & & \\
\hline
\end{tabular}


TABle 2: Continued.

\begin{tabular}{|c|c|c|c|c|c|c|}
\hline No & Plant part & $\begin{array}{l}\text { Chemical } \\
\text { type }\end{array}$ & Chemical & Structure & Activity & Ref \\
\hline 20 & & & Allo-ocimene & & & \\
\hline 21 & Leaves & $\begin{array}{c}\text { Essential } \\
\text { oils }\end{array}$ & A-terpinene & & $\begin{array}{l}\text { Antioxidant/ } \\
\text { antimicrobial }\end{array}$ & [25] \\
\hline 22 & & & (E)- $\beta$-ocimene & & & \\
\hline 23 & & & Quercetin & & & \\
\hline 24 & Leaves & Flavonoids & Catechin & & Antioxidant/anticancer & [26] \\
\hline 25 & & & Epicatechin & & & \\
\hline
\end{tabular}


TABle 2: Continued.

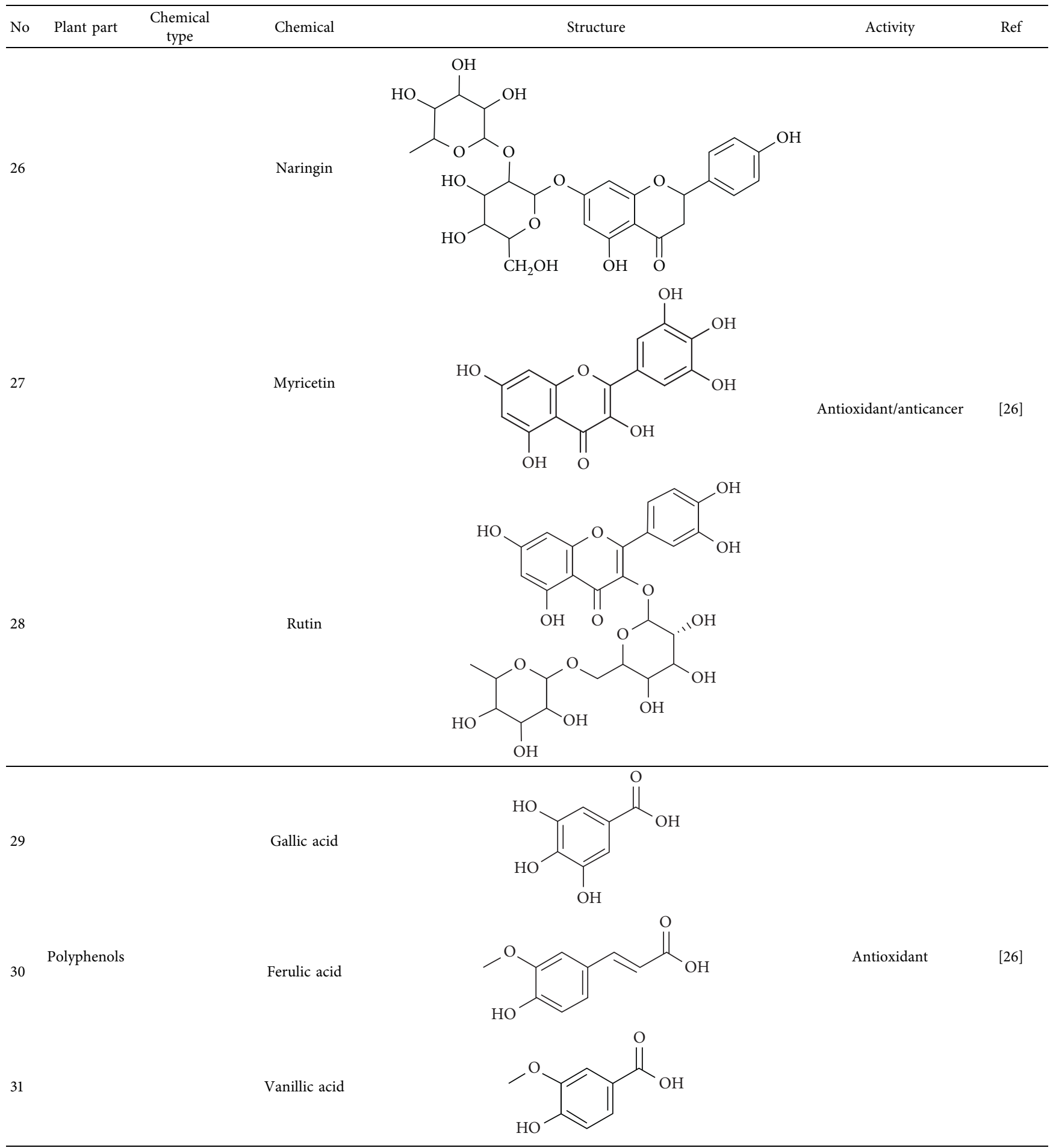

possibly pave the way for more natural drugs in treating diabetes and its related disorders.

The loss of pain perception occurs in diabetic patients due to damage of nerves. An experiment was made to investigate the pain threshold of the streptozotocin-induced diabetic rats after administering a dose of 300 and $500 \mathrm{mg} / \mathrm{kg}$ ethanolic extract of $M$. koenigii. The increased latency time in streptozotocin-induced diabetic rats suggested pain perception in the tested animal model. Therefore, the ethanolic extract of $M$. koenigii significantly decreased the glycemic level and prevented the progression of neuropathy in the diabetic animal model [49]. Furthermore, among hundreds of plants that have been studied for diabetes, M. koenigii is under clinical trials. One clinical research indicated a transient reduction in fasting and postprandial blood sugar levels in non-insulin-dependent diabetes 
TABLE 3: The major bioactive compounds of M. minutum and their pharmacological activities.

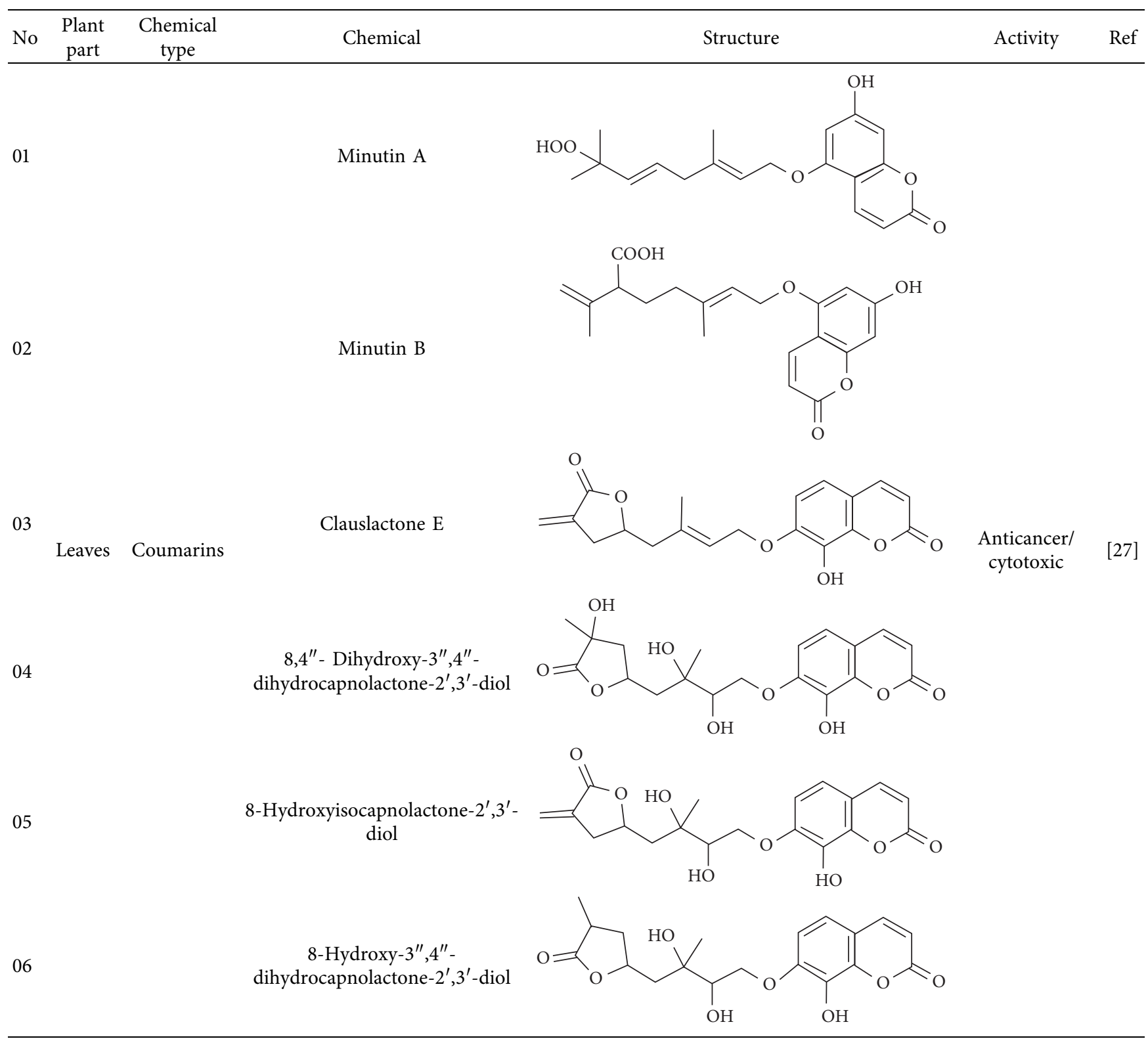


TABle 3: Continued.

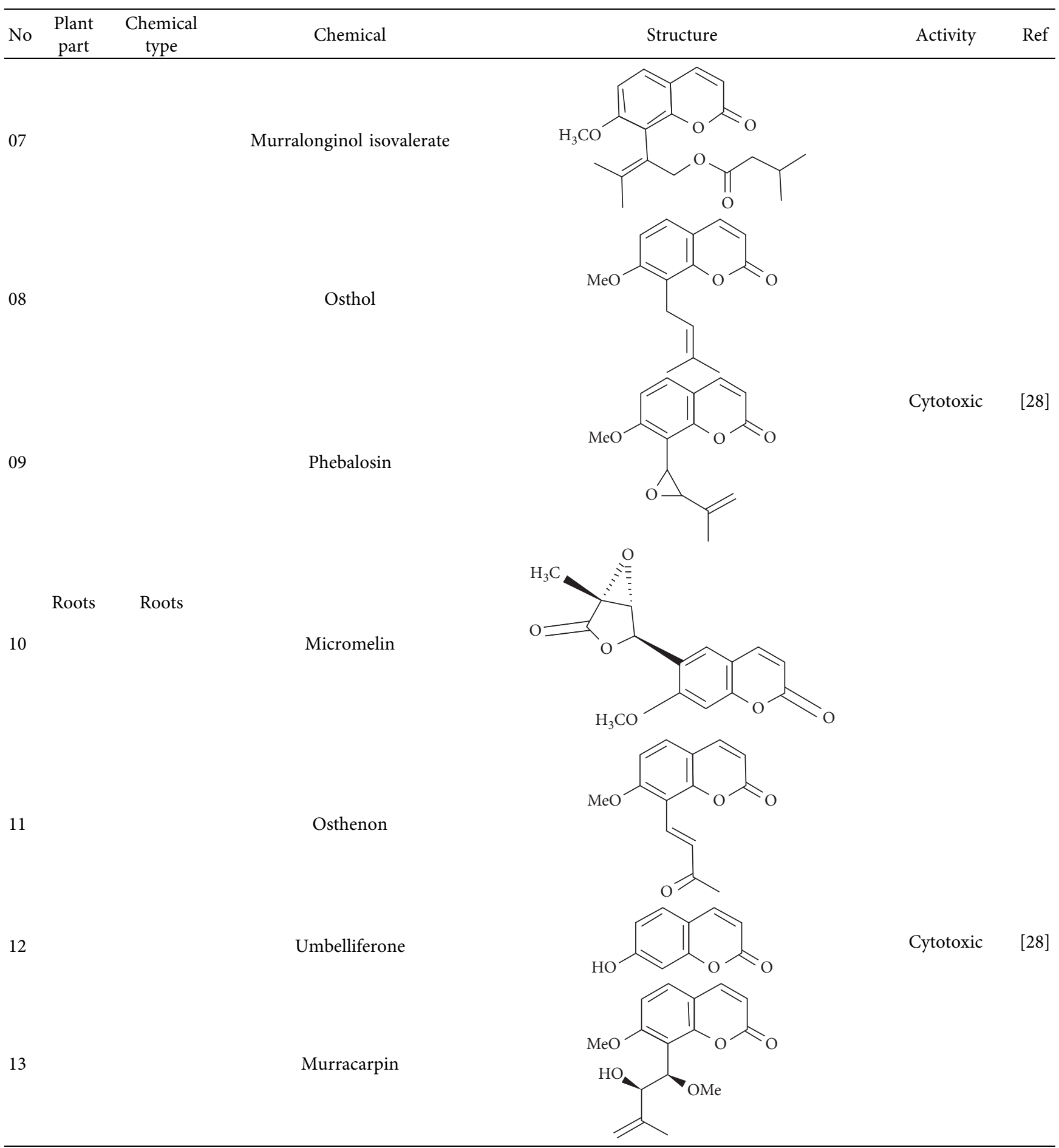


TABle 3: Continued.

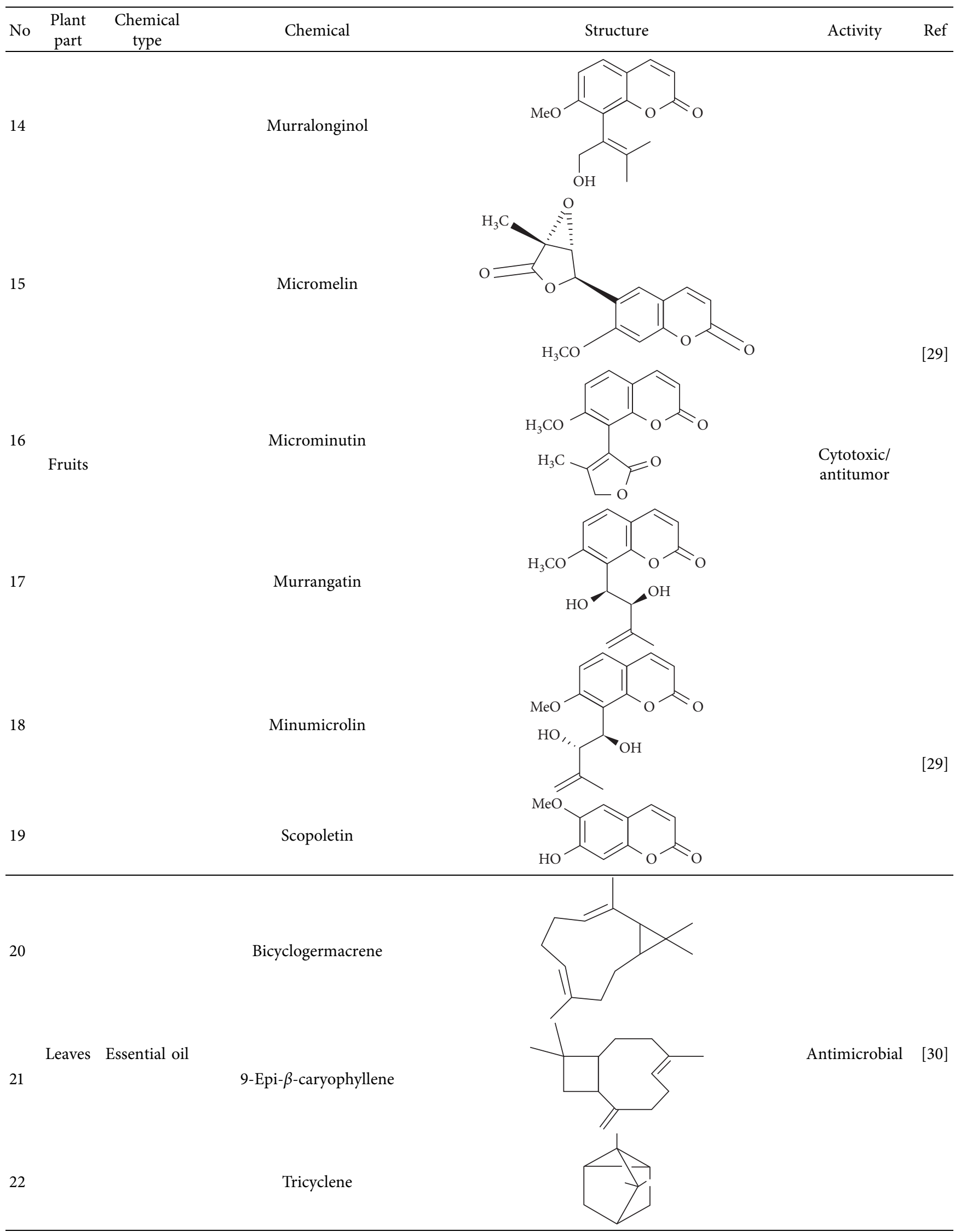


TABLE 4: The major bioactive compounds of $C$. indica and their pharmacological activities.

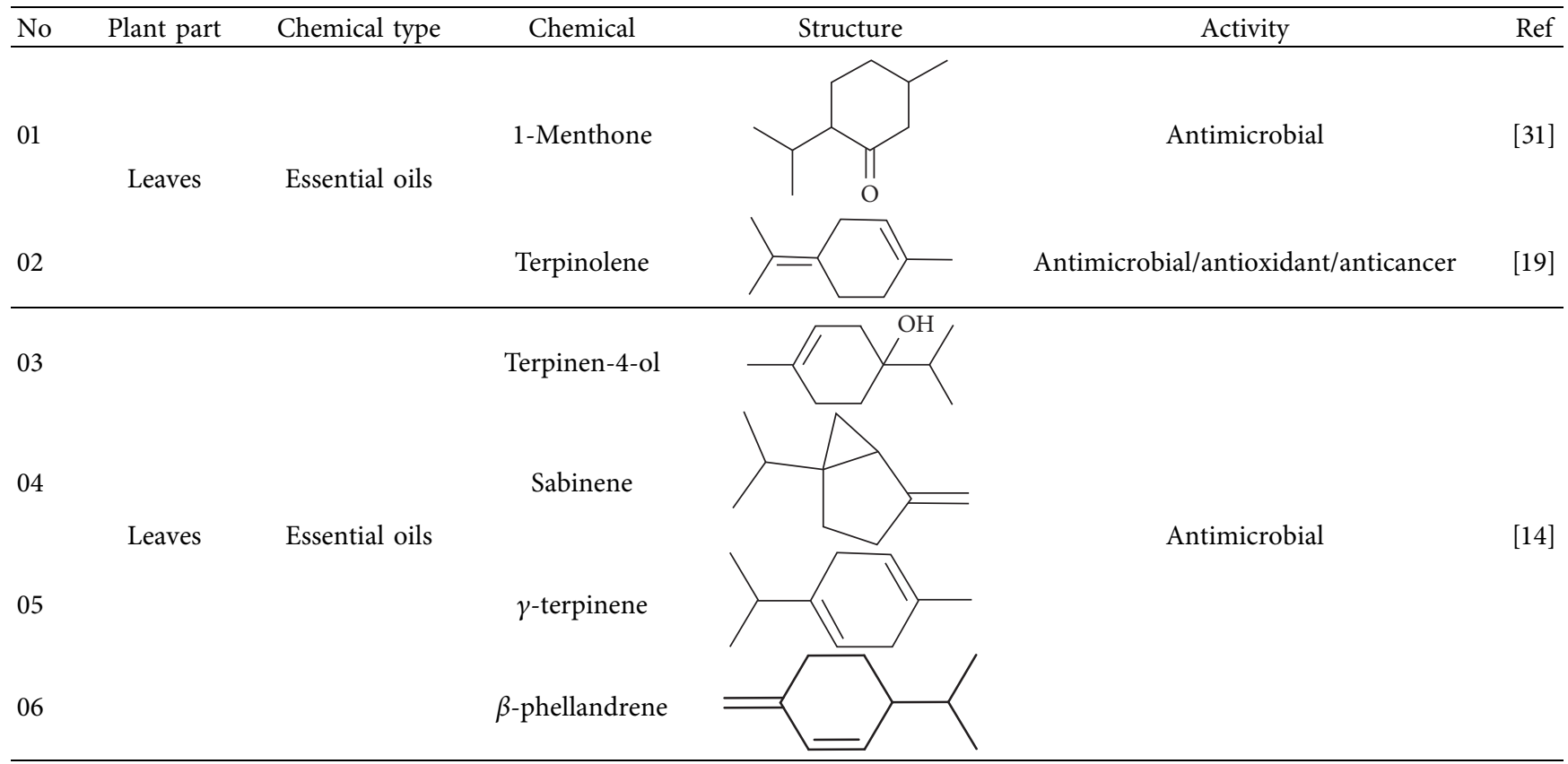

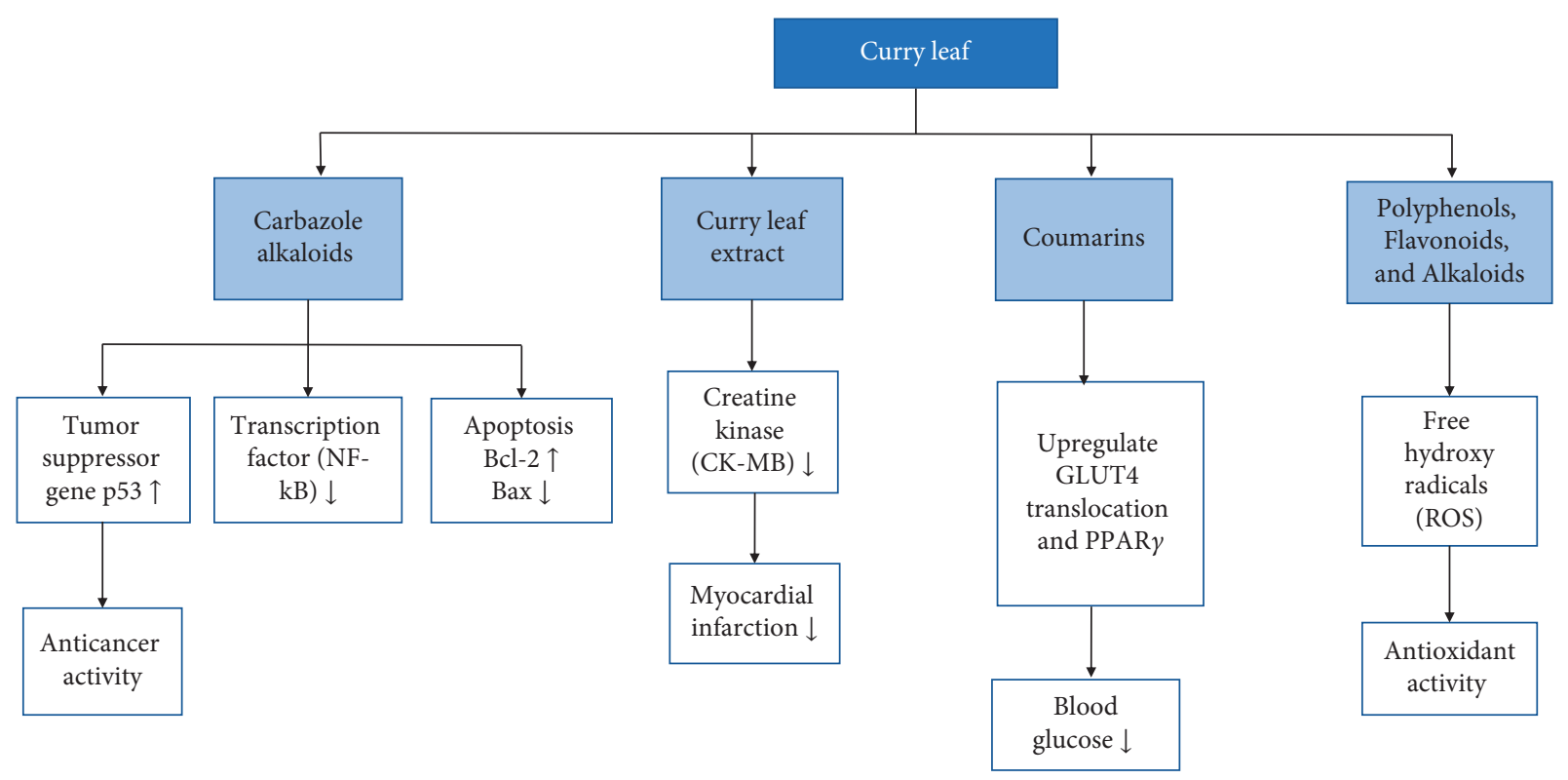

FIGURE 3: Modulation of different cell signaling pathways in disease management by the phytoconstituents in curry leaf.

mellitus patients provided with $12 \mathrm{~g}$ of $M$. koenigii leaves powder supplementation [50]. Among a wide range of phytochemical compounds isolated from $M$. koenigii, only a few compounds have been investigated on their antidiabetic potential. A study reported an in vitro antidiabetic activity in L6-GLUT4myc myotubes and in vivo studies of streptozotocin-induced diabetic rats with six major carbazole alkaloids, koenidine, murrayazoline, koenimbine A, koenidine, mahanimbine, and O-methylmurrayamine, extracted from M. koenigii leaves. The results revealed the potential use of koenidine in managing type II diabetes with insulin resistance [51].

The effect of $M$. minutum seeds ethanolic extract with coumarin and microminutinin has been shown to lower serum glucose levels in diabetic rats. A significant decrease in glucose levels was observed after administering coumarin $(100 \mathrm{mg} / \mathrm{kg})$ and microminutinin $(25 \mathrm{mg} / \mathrm{kg})$. The in vivo study further demonstrated the potential of using M. minutum seeds in treating hyperglycemia [13]. Similarly, the development of antidiabetic agents from $C$. indica roots 
has been investigated by bioguided isolation of the ethyl acetate extract. The isolates, dentatin, clausine $\mathrm{K}$, and nordentatin, demonstrate anti- $\alpha$-amylase activity suggesting the hypoglycemic activity of $C$. indica roots [52]. A recent study with ethyl acetate and hexane extracts of $C$. indica fruit identified coumarins as major compounds demonstrating anti- $\alpha$-amylase activity [53]. Therefore, $C$. indica and M. minutum, too, could be promising sources of antidiabetic agents.

The active compounds of $M$. koenigii, $C$. indica, and M. minutum play a pivotal role in preventing and treating diabetes mellitus. Even though the exact molecular mechanism in this vista is not understood fully, it was considered that their constituents play a vital role in the modulation of various cell signaling pathways, including insulin secretion. Many of the experiments discussed above are attributed to the presence of coumarins, carbazole alkaloids, and their derivatives in the $M$. koenigii, $C$. indica, and $M$. minutum extracts, as they are considered to be potent antihyperglycemic agents [54]. Carbazole alkaloids such as mahanimbine and koenimbin can increase peripheral glucose uptake. The phytochemicals in the extracts protect the pancreatic islets and the $\beta$ cells, in addition to the enhanced secretion and sensitivity of insulin from the pancreas, as suggested by various studies. Umbelliferone and osthole are the most common coumarins studied to modulate molecular pathways in diabetes and its complications [54].

Peroxisome proliferator-activated receptor $\gamma(\operatorname{PPAR} \gamma)$ is an essential nuclear hormone receptor acting on the transcription of genes (e.g., glucose transporter gene GLUT4) involved in glucose disposal. A study finding reveals that umbelliferone upregulated the expression of surface GLUT4 gene and $\operatorname{PPAR} \gamma$ in adipose tissue, enhancing insulin sensitivity leading to increased peripheral glucose uptake [55]. Osthole also activated $\operatorname{PPAR} \gamma$, increasing insulin sensitivity, and facilitated the synthesis and storage of fat [56]. The activation of these PPARs may also suppress inflammation. Umbelliferone further helps cells resist oxidative stress by facilitating the biosynthesis of enzymes responsible for radical attacks such as superoxide dismutase (SOD) and glutathione (GSH) [57]. In another perspective, umbelliferone inhibited the hydroxyproline level reducing the production of misfolded collagen in helping to treat collagen-induced diabetic nephropathy [54].

Keeping in view the tremendous antidiabetic studies and availability of literature, $M$. koenigii represents a promising candidate with potential use for the management of diabetes mellitus. Therefore, M. koenigii represents the clinical potential of developing a safe therapeutic drug confirmed with further preclinical and clinical research. Although plenty of evidence demonstrates that coumarins and other metabolites are effective against hyperglycemia, there had been no adequate investigations reported on the involvement of C. indica and M. minutum in hyperglycemia.

2.2. Anticancer and Cytotoxic Activities. Cancer involves multiple genetic alterations, unlike other monogenic disorders. The onset of cancer typically consists of a series of mutations in the genome resulting in uncontrolled cell proliferation, lack of apoptosis, and alterations in epigenetic regulations. Nearly ten million new cancers are diagnosed annually, making it the second most common cause of mortality worldwide [58]. Typical treatment strategies for most cancers include radiation therapy, hormone therapy, chemotherapy, and surgical tumor resections. Despite the drawbacks, including multidrug resistance in cancer cells and nonspecific targeting, chemotherapy remains the predominantly used treatment in many cancers. However, growing interest in using natural compounds paves the way for new perspectives in chemotherapy studies. M. koenigii and $M$. minutum have been reported to have a potential role as a remedy for cancer and inflammation. The preliminary approach for any potent anticancer compound from natural sources is an investigation of in vitro cytotoxicity studies on various cell lines. Numerous studies have been carried out on isolating natural compounds and understanding their antitumor and cytotoxic activities. $M$. koenigii and M. minutum also have been successfully addressed in this regard.

Constituents M. koenigii, C. indica, and M. minutum play an essential role in the modulation of various signaling pathways in the cell. These constituents upregulate the tumor suppressor genes $p 53$ and downregulate the genes responsible for developing cancer, such as NF- $\kappa \mathrm{B}$. Furthermore, various carbazole alkaloids and coumarins of these curry leaves activate the cyclooxygenase pathway and apoptosis.

\subsubsection{Effect of Curry Leaves and Their Constituents on} Cytotoxicity. Some chemotherapeutic drugs have proved to be highly cytotoxic agents to normal cells, as seen in clinical studies. However, the preferential cytotoxicity against malignant tissues is crucial in a suitable treatment. Plants and their derivatives play an essential role in the cytotoxicity studies searching for an alternative for chemotherapeutic drugs with selected toxicity towards cancerous cells. Active compounds in a plant extract target cell lines and significantly affect cytotoxicity.

An experimental study reported the cytotoxic activities of alkaloid extract from $M$. koenigii in the breast cancer cell line MDA-MB-231 with an $\mathrm{IC}_{50}$ of $14.4 \mu \mathrm{g} / \mathrm{mL}$ [59]. Mahanine, a carbazole alkaloid isolated from M. koenigii and M. minutum, and its analogs have shown significant cytotoxic and anticancer activities in prostate cancer studies. Prostate cancer, the most commonly diagnosed cancer in men worldwide, is associated with alterations in androgen receptor functions. Studies have shown the functions of mahanine related to the androgen receptor, inhibiting ligand-dependent and -independent transactivation leading to a significant decrease in the expression of androgenregulated genes. Furthermore, mahanine results in proteasomal degradation by compromising the stability of the androgen receptor [60]. Another study with a combination of mahanine and cisplatin, a drug used in cervical cancer treatments, reported cytotoxicity even at reduced concentrations [61]. The dual combination of mahanine and 
cisplatin inhibited cancer cell migration and was further suggested to be a prospective combination for cancer treatment due to the lower toxicity reported.

In another study, mahanine isolated from M. minutum executed apoptosis through the intrinsic pathway in human leukemia U937 cells [62]. A study with M. minutum leaves methanol extract composed of six coumarins including minutin A, minutin B, 8,4"-dihydroxy-3" $4^{\prime \prime}$-dihydrocapnolactone- $2^{\prime}, 3^{\prime}$-diol, 8 -hydroxyisocapnolactone2',3'-diol, 8-hydroxy-3", $4^{\prime \prime}$-dihydrocapnolactone-2', $3^{\prime}$-diol, and clauslactone $\mathrm{E}$ reported a significant cytotoxic activity against lung adenocarcinoma (A549 and SBC3) and leukemia (K562 and K562/ADM) cell lines [27]. Furthermore, 8-hydroxyisocapnolactone- $2^{\prime}, 3^{\prime}$-diol displayed significant cytotoxic activity against both cervical cancer (HeLa) and liver cancer (HepG2) cell lines suggesting potential nutraceutical chemopreventive agents from $M$. minutum leaves.

Specific cytotoxicity activities of the extracts of M. minutum roots and its isolates were reported to have inhibitory effects against the KB cell line and weak cytotoxicity against the NCI-H187 cell line providing a basis for the use of M. minutum roots in the treatment of cancers [28]. The various preclinical human carcinoma models are to be further investigated on in vivo efficacy to promote various isolates of M. koenigii and M. minutum to be used in treatments in carcinoma.

2.2.2. Effect of Curry Leaves and Their Constituents on Apoptosis. Apoptosis is a typical biochemical function that induces the committing of cell death of pointless cells. Resistance towards apoptosis is a crucial factor of tumor cells. Therefore, any search for the new chemotherapeutic agent that can induce apoptosis is enhanced by understanding apoptotic pathways. The two main pathways of apoptosis are intrinsic and extrinsic. External death signals trigger apoptosis in extrinsic pathways, and intrinsic pathways are mediated by Bcl-2-associated X protein (Bax) and Bcl-2 antagonist. Any alteration in Bcl-2 and Bax causes the development of cancers [63].

Several investigations provided evidence of the proapoptosis functions of the M. koenigii- and M. minutumderived extracts and phytochemicals, including carbazole alkaloids such as mahanine, mahanimbicine, girinimbine, mahanimbine, and coumarins. A valuable study on the effect of mahanine in prostate cancer reported the induction of apoptosis in cancer cells. Several bioactive compounds, including girinimbine, a carbazole alkaloid isolated from $M$. koenigii, have been reported to potentially inhibit inflammation and induce apoptosis in human colon cancer cells (HT-29) in vitro [64]. The induction of apoptosis by girinimbine was also evidenced in vivo in a 24-hour treatment of zebrafish embryos, indicating a significant distribution of apoptotic cells in embryos. These findings strongly suggest a potential for girinimbine to be further examined for its use in treating cancer as a chemotherapeutic agent. Another in vitro study of girinimbine on A549 lung cancer cells about apoptotic mechanistic pathways has demonstrated a successful induction of the early phase of apoptosis as indicated by stability assays [65]. Furthermore, the use of girinimbine and its derivatives as a herbal remedy in combinational chemotherapeutics have been recommended in several other in vitro and in vivo studies $[65,66]$.

These findings strongly represent the notion that girinimbine has a significant involvement in both intrinsic and extrinsic pathways of apoptosis. Moreover, girinimbine upregulates the p53 the key tumor suppressor protein, and the cyclin-dependent kinase (CDK) proteins, p27 and p21. The overexpression of CDK proteins inhibits abnormal cancer cell proliferation and promotes cell cycle arrest at the G1 phase. Additionally, girinimbine activated apoptosis via regulating the intrinsic pathway by the downregulated Bcl-2 protein expression and upregulated Bax [27, 63]. Another study revealed that girinimbine-treated HepG2 cells ultimately led to apoptosis through $G_{0} / G_{1}$ phase arrest [67]. In this regard, a large amount of work has been done with girinimbine to study its effectiveness on diverse cancer types.

Koenimbine, another dietary component isolated from $M$. koenigii, has been studied to evaluate the efficacy of the inhibition of MCF7 breast cancer cells through apoptosis [68]. This study adds insight into the ability of koenimbine to trigger apoptosis in breast cancer cells in vitro. One possible mechanism of koenimbine in apoptosis in breast cancer cells could be the downregulation of the Wnt/ $\beta$-catenin self-renewal pathways. Similarly, koenimbine has remarkably inhibited cell proliferation of prostate cancer stem cells in a recent study [69].

In a previous study, C. indica roots were used to purify few compounds, including dentatin, nordentatin, and clausine $\mathrm{K}$, with anticarcinogenic properties [52]. In addition, C. indica is reported to be a rich source of phytochemical components such as sesquiterpenes, coumarins, and carbazole alkaloids which might have a strong potential for anticancer activity. Nevertheless, there is still room for studies on $C$. indica, which needs to be screened for the novel, cost-effective, and efficacious anticancer agents.

\subsubsection{Effect of Curry Leaves on NF- $\kappa b$ Transcription Factor.} The transcription factor, NF- $\kappa \mathrm{B}$ transcription factor, has a pivotal role in human cancers. The overexpression of NF- $\kappa \mathrm{B}$ induces antiapoptosis and angiogenesis and promotes tumors. Several stimuli such as cellular and environmental stresses, DNA damage, growth factors, and cytokines activate NF- $\kappa$ B. Therefore, the inhibition of NF- $\kappa$ B is crucial in the prevention and control of cancer. A study evaluated the chemopreventive activity of $M$. koenigii leaf extract on 4T1 breast cancer cell-challenged mice. The results confirmed those aqueous leaf extracts significantly prevented tumor formation compared to the untreated group of mice. The activation of NF- $\kappa \mathrm{B}$ is induced by the cytokines cytokineIL$1 \beta$ and pleitropic cytokine IL- 6 was found to be reduced in the $M$. koenigii-treated $4 \mathrm{~T} 1$ breast cancer cell-challenged mice [70].

2.3. Effect on Cardiovascular Diseases. Cardiovascular diseases are the number one cause of death in the world. According to WHO, cardiovascular diseases in the elderly 
population have created 18 million deaths in the year 2016, resulting in $31 \%$ of deaths in the globe [71]. Atherosclerosis is one of the major causative factors for cardiovascular disease due to the blockages that prevent blood from flowing to the heart or brain due to the building up of fatty deposits on the inner walls of the blood vessels. Abnormally increased levels of lipids in the blood, triglycerides, phospholipids, cholesterol, and cholesterol esters trigger atherosclerosis. The different types of cholesterol, High-Density Lipoprotein (HDL), Low-Density Lipoprotein (LDL), and Very LowDensity Lipoprotein VLDL, have a massive impact on the prevalence of cardiovascular disease.

Various studies are undertaken to evaluate the antihyperlipidemic potential of the M. koenigii leaf extracts. The biochemical response of $M$. koenigii was studied on various types of cholesterols in a study with Albino rats. These researchers fed Albino rats a diet fortified with $20 \%$ coconut oil with $10 \%$ M. koenigii leaf feed for three months. An increase in HDL and reduced LDL, VLDL, and total serum cholesterol levels were observed in the experiment [72]. In another study, the effect of $M$. koenigii aqueous leaf extract of $300 \mathrm{mg} / \mathrm{kg}$ on the biochemical response in normal and STZinduced severe diabetic rats were evaluated. The results confirmed a decrease of $22.9 \%$ and $37.1 \%$ of triglyceride level and $19.2 \%$ and $30.3 \%$ in total cholesterol in normal and diabetic rats, respectively, in one month [39].

The potency of $M$. koenigii leaf on lowering blood cholesterol levels could be ascertained by various experimental conditions, including the study's duration, the type of animal model or the form of $M$. koenigii leaf used, or the solvent used for the extraction. Another finding showed that obese diabetic ob/ob mice given $80 \mathrm{mg} / \mathrm{kg}$ aqueous M. koenigii extract for ten consecutive days have significantly decreased blood cholesterol levels from $277.6 \pm 16.6 \mathrm{mg} /$ day (day 0) to $182.0 \pm 15.3 \mathrm{mg} /$ day [73]. In addition, the dichloromethane and ethyl acetate extracts of M. koenigii leaves lowered body weight gain in high-fat diet-induced obese rats at oral administration of $30 \mathrm{mg} / \mathrm{kg} /$ day.

Creatine kinase (CK-MB) is a well-known heart enzyme and a cardiac biomarker found primarily in the cardiac muscle. A study assessed the effect of $M$. koenigii aqueous extract (180 mg/kg body weight) on albino Wistar rats treated with Voltral tablets to increase the level of CK$\mathrm{MB}$ [74]. A significant decrease of the heart enzyme CK$\mathrm{MB}$ was observed in rats treated with $M$. koenigii compared to the group treated with atenolol, a drug available in the market as a beta blocker, further suggesting a potential role of $M$. koenigii in lowering CK-MB in myocardial infarction.

M. minutum seed, a rich source of coumarins [29], has been used to investigate the efficacy of the variation of serum cholesterol, triglycerides, HDL, and LDL levels in diabetic rats [13]. In that study, a significantly increased HDL was observed with the administration of $100 \mathrm{mg} / \mathrm{kg}$ ethanolic extract of M. minutum seeds in rats. However, no report on the potency of $C$. indica on treating or reducing cardiovascular biomarkers was found in the literature.
2.4. Antimicrobial Activity. The occurrence of microbial drug resistance of many microorganisms and their complications are growing worldwide. Therefore, antibiotic resistance has become one of the major issues since the late $20^{\text {th }}$ century's rising demand for new antimicrobial agents. However, most new antimicrobial agents fail after many clinical trials and treatments due to the side effects and rapid resistance development. Traditionally, M. koenigii, M. minutum, and C. indica are well known for their health benefits and are rich in antimicrobial activities owing to the presence of a variety of essential phytochemicals and many secondary plant metabolites, such as tannins, terpenoids, alkaloids, flavonoids, phenols, and quinines present in their leaves and seeds [75].

The biodeterioration of food due to microorganisms causes a significant loss to crop from vegetables, grains to fish, and poultry. Many plant extracts have been reported to display antifungal, antibacterial, and insecticidal properties in vitro. Therefore, aqueous extracts of widely used culinary spices, including M. koenigii, were screened in a research study against several microorganisms found on edible fish to identify their antimicrobial activities [76]. M. koenigii has shown a significant antibacterial activity towards various pathogenic bacterium types found in edible fishes. The minimum inhibitory concentration (MIC) of $M$. koenigii on Staphylococcus aureus (S. aureus) was $250 \mu \mathrm{g} / \mathrm{ml}$ and $500 \mu \mathrm{g} /$ $\mathrm{ml}$ on Escherichia. coli (E. coli), Lactobacillus spp., Salmonella typhi (S. typhi), and Shigella spp. Both methanol and aqueous extracts of $M$. koenigii showed antibacterial activity among all the herbs extracts tested in the study suggesting the use of $M$. koenigii in cooking to eradicate the respective bacteria and as a food preservative.

An investigation was carried out to screen twenty medicinal plant extracts against seed-borne fungi in seeds, causing weight and quality losses leading to the reduction of commercial value. This study was aiming at the efficacy of M. koenigii on seed-borne fungi species. M. koenigii was reported to have a remarkable mycelial growth inhibitory effect against all the seed-borne fungi used in the experiment. However, the highest inhibition of mycelial growth was observed in Alternaria alternata [77]. In view of these, MICs of bactericidal and fungicidal activities were reported for methanolic, ethanolic, and acetonic leaf extracts of M. koenigii in a study [78]. Acetonic and methanolic extracts showed the highest susceptibility for the bacterial species tested, indicating the role of the extraction efficiency of bioactive compounds in different solvents.

In evaluating the antioxidant property of $M$. koenigii plant parts, bark extract is the least common among researchers. Few investigators have used the agar cup-plate method in accessing the antibacterial activity of different microbial species of the bark and leaf extracts. Bark extracts have shown a significant inhibitory activity compared to the leaf extracts of $M$. koenigii, and the most susceptible species was $S$. aureus [33]. Leaf and seed extracts of $M$. koenigii in different solvents, acetone, chloroform, ethanol, and methanol, have been studied for their antimicrobial activities. The study results indicated that the acetone and 
methanol extracts had higher antimicrobial activity than other solvents [79].

Another study revealed the in vitro antibacterial potential of the aqueous and ethanolic leaf extracts of M. koenigii against bacterial species accountable for endometritis. Bacillus sp., Salmonella sp., Staphylococcus sp., and Corynebacterium spp. are responsible for endometritis in domestic cows. Ethanol and aqueous extracts of M. koenigii showed a potent antimicrobial effect towards pathogens under study. The ethanolic extract showed a better response than the aqueous extract [80].

Essential oils extracted from plants have been recognized for their antioxidant and antimicrobial attributes for decades. Essential oils of M. koenigii leaves are rich in many phytochemicals, serving as antioxidant and antimicrobial agents [81]. The antimicrobial activities of essential oils from M. koenigii have been extensively explored recently. An experiment was made to evaluate the antifungal activity of methanol and ethanol extracts and the essential oils of $M$. koenigii leaves. The results indicated that all the extracts showed antifungal activity and methanol extract had the highest activity and essential oils with a moderate antifungal activity [79].

M. minutum is reported to be a rich source of antimicrobial compounds. Antibacterial potential of leaves, stem bark, and root bark ethanolic extracts of $M$. minutum against $E$. coli and $S$. aureus was investigated to validate its current use as alternative medicine in a study [82]. The inhibitory activities of the three ethanolic extracts towards $S$. aureus were significant when compared with E. coli. Among the three extracts, leaf extracts showed the highest zone of inhibition towards both bacteria species due to the prevalence of highly cytotoxic coumarin compounds and highly antimutagenic carbazole alkaloids. For instance, mahanine could explain the increased inhibitory activity of leaf extracts [82]. However, stem bark and root extracts of M. minutum showed partial activity towards $S$. aureus and inactivity towards E. coli in this study.

The essential oil from $M$. minutum is rich in sesquiterpenes germacrene, germacrene-B, $\delta$-elemene, and $\beta$ caryophyllene, having a potential antimicrobial activity [83]. The antimicrobial activity of $M$. minutum essential oils was investigated at a concentration of $0.25 \%-1 \%(\mathrm{v} / \mathrm{v})$ in a study. The results showed significant antimicrobial activity at $1 \% \mathrm{v} / \mathrm{v}$ towards all the species under study [30].

A study was performed on the antibacterial activity of C. indica leaf essential oil extracts from South India, and significant activity against $B$. cereus, S. typhi, and $P$. vulgaris was observed [14]. However, no significant activity was reported against $E$. coli and $S$. aureus. Another experiment was made to evaluate the MIC of essential oils from $C$. indica from Vietnam towards selected Gram-negative and Grampositive bacteria. The results showed significant antibacterial activity against E. coli and S. aureus. In addition, the MIC of various fungi strains was also tested, and interestingly, the essential oil was inactive for all the tested fungi species [14]. Therefore, the results of antibacterial assay for E. coli and $S$. aureus are contradictory in the studies conducted in South India and Vietnam, signifying a difference in their chemical profiles. The essential oil from $C$. indica from Vietnam leaf contains terpenes, mainly terpinolene, and myristicin, as the major constituents [19]. At the same time, sabinene was the major component in the same species from South India [14].

Hardly any literature was found on the antimicrobial activity of M. koenigii or M. minutum fruits, but the antimicrobial activity of $C$. indica fruits has recently been reported [84]. Flavonoids, a significant constituent in the fruits of $C$. indica, have shown significant antimicrobial effects against the Gram-positive bacteria, and no activity was reported for the tested fungi and yeast species [84]. Microorganisms tested for the antimicrobial potential of M. koenigii, M. minutum, and C. indica observed in literature are tabulated in Table 5.

2.5. Antioxidant Properties. Medicinal plants are excellent natural antioxidants that can be used to prevent diseases such as cancer, heart diseases, strokes, and inflammation [94]. The secondary metabolites, phenolics, flavonoids, and carotenoids are found in almost all parts of medicinal plants, and they have been reported to have potent free radical scavengers and antioxidant properties [95]. The growing interest in antioxidants from natural sources has attracted the scientific community recently, as synthetic antioxidants have several side effects such as the risk of liver damage and carcinogenesis in animals [96, 97].

M. koenigii plays a vital role among the traditionally important medicinal plants utilized in Asian ayurvedic practices due to their health benefits and therapeutic actions [95]. Various direct and indirect methods have assessed the antioxidant activities of the plants of the Rutaceae family. Most parts of $M$. koenigii are reported to be a rich source of plant polyphenols, flavonoids, and alkaloids, possessing a high antioxidant potency [98-100]. A recent study reported that total antioxidant activity was the highest in M. koenigii (2691 $\mu \mathrm{mol}$ of ascorbic acid/g sample) among green leafy vegetables [101]. The in vitro antioxidant property of leaf extracts of $M$. koenigii has been studied in different solvents/ solvent mixtures such as water, methanol, hexane, water: ethanol, or chloroform with $\mathrm{DPPH}, \mathrm{Fe}^{3+}$ ion reducing method, and hydroxy radical scavenging activity [102]. All samples varied in their antioxidant potential depending on the chemical composition and the solvent. Nevertheless, the $1: 1$ (water: ethanol) mixture leaf extract exhibited the maximum antioxidant activity. Interestingly, the $1: 1$ (water : ethanol) mixture was able to scavenge approximately $90 \%$ of $\mathrm{DPPH}$ and hydroxyl radicals at 4-5-fold lower concentrations than all the other tested solvent extracts. The observation of water: ethanol mixture leaf extract with the highest scavenging activity is in accordance with a study that used response surface methodology to optimize the solvent concentration and extraction time in maximizing the yield of M. koenigii leaf extracts to determine the total phenol content and DPPH assay. The 50\% ethanol extract showed the highest scavenging ability and total phenolic content [103].

The $\mathrm{H}_{2} \mathrm{O}_{2}$ scavenging method has been used to screen the total antioxidant activity of $M$. koenigii acetone and 
TABLE 5: Microorganisms tested for the antimicrobial potential of Murraya koenigii ${ }^{\mathrm{a}}$, Micromelum minutum ${ }^{\mathrm{b}}$, and Clausena indica $^{\mathrm{c}}$.

\begin{tabular}{|c|c|c|c|c|}
\hline & & Species tested & Solvent & Ref \\
\hline Leaves $^{\mathrm{a}}$ & Well diffusion method & $\begin{array}{c}\text { Staphylococcus aureus } \\
\text { Salmonella typhi } \\
\text { Shigella spp. } \\
\text { Escherichia coli } \\
\text { Lactobacillus spp. }\end{array}$ & Water, methanol & {$[76]$} \\
\hline Leaves $^{\mathrm{a}}$ & Well diffusion method & $\begin{array}{c}\text { Alternaria alternata } \\
\text { Aspergillus flavus } \\
\text { Aspergillus niger } \\
\text { Curvularia lunata } \\
\text { Fusarium moniliforme } \\
\text { F. solani } \\
\text { Helminthosporium sativum } \\
\text { Penicillium spp. }\end{array}$ & Water & {$[78]$} \\
\hline Leaves $^{\mathrm{a}}$ & Well diffusion method & $\begin{array}{c}\text { Aspergillus niger } \\
\text { Fusarium oxysporum } \\
\text { Penicillium notatum } \\
\text { Trichoderma viride } \\
\text { Bacillus cereus } \\
\text { Escherichia coli } \\
\text { Staphylococcus aureus } \\
\text { Salmonella typhi } \\
\end{array}$ & Acetone, methanol, ethanol & {$[77]$} \\
\hline Seeds ${ }^{\mathrm{a}}$ & Disk diffusion method & $\begin{array}{c}\text { Klebsiella pneumoniae } \\
\text { Staphylococcus aureus } \\
\text { Pseudomonas aeruginosa } \\
\text { Bacillus subtilis }\end{array}$ & Acetone, chloroform, ethanol, methanol & {$[85]$} \\
\hline Leaves and bark ${ }^{\mathrm{a}}$ & Agar cup-plate method & $\begin{array}{c}\text { Staphylococcus aureus } \\
\text { Proteus vulgaris } \\
\text { Enterobacter aerogenes } \\
\text { Lactobacillus spp. }\end{array}$ & Ethanol & [33] \\
\hline Leaves and seed ${ }^{a}$ & Disk diffusion method & $\begin{array}{c}\text { Klebsiella pneumoniae } \\
\text { Staphylococcus aureus } \\
\text { Pseudomonas aeruginosa } \\
\text { Bacillus subtilis }\end{array}$ & Acetone, chloroform, ethanol, methanol & {$[85]$} \\
\hline $\begin{array}{l}\text { Leaves and } \\
\text { essential oils }^{\mathrm{a}}\end{array}$ & Well diffusion method & $\begin{array}{c}\text { Fusarium oxysporum } \\
\text { Rhizoctonia solani }\end{array}$ & Methanol, ethanol & {$[79]$} \\
\hline Leaves $^{\mathrm{a}}$ & Well diffusion method & $\begin{array}{c}\text { Escherichia coli } \\
\text { Corynebacterium spp. } \\
\text { Staphylococcus spp. } \\
\text { Bacillus spp. } \\
\text { Salmonella spp. }\end{array}$ & Water, ethanol & {$[80]$} \\
\hline Leaves $^{\mathrm{a}}$ & Well diffusion method & $\begin{array}{c}\text { Streptococcus mutans } \\
\text { Streptococcus gordonii } \\
\text { Pseudomonas aeruginosa } \\
\text { Candida albicans }\end{array}$ & Water, methanol, ethanol, n-hexane & {$[86]$} \\
\hline Leaves $^{\mathrm{a}, \mathrm{b}}$ & Well diffusion method & $\begin{array}{c}\text { Bacillus cereus } \\
\text { Pseudomonas aeruginosa } \\
\text { Staphylococcus aureus }\end{array}$ & Water, methanol, ethanol & {$[87]$} \\
\hline Leaf $^{a}$ & Cup diffusion method & $\begin{array}{c}\text { Xanthomonas axonopodis } \\
\text { pv. vesicatoria } \\
\text { Xanthomonas campestris pv. } \\
\text { campestris } \\
\text { Pseudomonas syringae } \\
\text { Aspergillus flavus } \\
\text { Fusarium verticillioides }\end{array}$ & Chloroform, ethyl acetate, methanol & {$[88]$} \\
\hline
\end{tabular}


TABle 5: Continued.

\begin{tabular}{|c|c|c|c|c|}
\hline & & Species tested & Solvent & Ref \\
\hline Shoots ${ }^{\mathrm{a}}$ & Well diffusion method & $\begin{array}{c}\text { Escherichia coli } \\
\text { Staphylococcus aureus } \\
\text { Pseudomonas aeruginosa } \\
\text { Salmonella typhi } \\
\text { Bacillus cereus } \\
\text { Klebsiella pneumoniae } \\
\text { Candida albicans }\end{array}$ & $\begin{array}{l}\text { n-Hexane, ethyl acetate, butanol, chloroform, } \\
\text { water }\end{array}$ & [89] \\
\hline Essential oil $^{\mathrm{a}}$ & Broth dilution method & $\begin{array}{c}\text { Staphylococcus aureus } \\
\text { Escherichia faecalis } \\
\text { Escherichia coli } \\
\text { Pseudomonas aeruginosa } \\
\text { Candida albicans } \\
\text { Candida parapsilosis } \\
\text { Aspergillus fumigatus } \\
\text { Aspergillus niger }\end{array}$ & & {$[90]$} \\
\hline Leaf $^{a}$ & Well diffusion method & $\begin{array}{c}\text { Staphylococcus aureus } \\
\text { Bacillus cereus } \\
\text { Micrococcus luteus } \\
\text { Escherichia coli } \\
\text { Klebsiella pneumoniae }\end{array}$ & Water & [91] \\
\hline Leaf $^{a}$ & Well diffusion method & $\begin{array}{c}\text { Staphylococcus aureus } \\
\text { Bacillus cereus } \\
\text { Micrococcus luteus } \\
\text { Escherichia coli } \\
\text { Pseudomonas aeruginosa } \\
\text { Klebsiella pneumoniae } \\
\text { Aspergillus niger } \\
\text { Candida albicans } \\
\text { Candida tropicalis } \\
\text { Cryptococcus neoformans } \\
\text { Candida kefyr }\end{array}$ & $\begin{array}{l}\text { Ethanol, methanol, ethyl acetate, acetone, } \\
\text { chloroform, petroleum ether, hexane, hot } \\
\text { water }\end{array}$ & {$[92]$} \\
\hline Leaf $^{a}$ & Disc diffusion method & $\begin{array}{c}\text { Staphylococcus aureus } \\
\text { Escherichia coli } \\
\text { Staphylococcus epidermidis } \\
\text { Pseudomonas aeruginosa } \\
\text { Klebsiella pneumonia } \\
\text { Proteus mirabilis } \\
\text { Proteus vulgaris } \\
\text { Candida albicans } \\
\text { Aspergillus fumigatus } \\
\end{array}$ & Water & {$[93]$} \\
\hline $\begin{array}{l}\text { Leaves, stem, and } \\
\text { root barks }{ }^{\mathrm{b}}\end{array}$ & Disk diffusion method & $\begin{array}{l}\text { Staphylococcus aureus } \\
\text { Escherichia coli }\end{array}$ & Ethanol & {$[82]$} \\
\hline Essential oil $^{\mathrm{b}}$ & Well diffusion method & $\begin{array}{c}\text { Staphylococcus aureus } \\
\text { Escherichia coli } \\
\text { Bacillus subtilis } \\
\text { Pseudomonas aeruginosa }\end{array}$ & & {$[30]$} \\
\hline Essential oil ${ }^{\mathrm{c}}$ & Broth diffusion method & $\begin{array}{c}\text { Escherichia coli } \\
\text { Pseudomonas aeruginosa } \\
\text { Bacillus subtilis } \\
\text { Staphylococcus aureus } \\
\text { Aspergillus niger } \\
\text { Fusarium oxysporum } \\
\text { Saccharomyces cerevisiae } \\
\text { Candida albicans } \\
\end{array}$ & & {$[15]$} \\
\hline Fruits $^{c}$ & $\begin{array}{l}\text { Filter paper diffusion method, LB } \\
\text { medium double dilution method }\end{array}$ & $\begin{array}{c}\text { Escherichia coli } \\
\text { Staphylococcus aureus } \\
\text { Bacillus subtilis } \\
\text { Mucor } \\
\text { Saccharomyces cerevisiae }\end{array}$ & & {$[84]$} \\
\hline
\end{tabular}


TABle 5: Continued.

\begin{tabular}{ccc}
\hline & Species tested & Solvent \\
\hline & Bacillus cereus & \\
& Salmonella typhi & Proteus vulgaris \\
Leaf essential oil & Escherichia coli & Bacillus subtilis \\
& Well diffusion method & Staphylococcus aureus \\
& Klebsiella pneumoniae & Serratia marcescens \\
\hline
\end{tabular}

petroleum ether leaf extracts. The mature leaf acetone extracts had a relatively greater scavenging activity by $50 \%$ compared to young leaves in petroleum ether [104]. A study was made to access the antioxidant activity of $M$. koenigii leaves in different solvent extracts, benzene, ethyl acetate, petroleum ether, acetone, methanol, and ethanol. It was evident that the benzene layer had the highest radical scavenging power, followed by ethyl acetate and petroleum ether [105]. This observation is further supported in another study, where the benzene fraction was found to have the highest total phenolic content and antioxidant activities [106]. Differences in extractability of the antioxidant components in a solvent with various polarities explain the varied antioxidant activities of $M$. koenigii in different solvents.

Another study was made to investigate the efficacy of $M$. koenigii powder as an antioxidant in in-ground goat meat and precooked goat meat. The results confirmed that the M. koenigii powder at $0.2 \%(\mathrm{w} / \mathrm{w})$ acts as an effective inhibitor for oxidation products formed during raw ground and precooked meat during storage [99]. Many other studies have reported the antioxidant potential of the $M$. koenigii plant as a whole or various isolates from its bark, leaves, roots, or fruits with various methods and solvents, suggesting the pronounced antioxidant activity of $M$. koenigii $[24,85,105]$.

An important study was made based on evaluating the antioxidant activity of $M$. minutum bark extract and the active fractions isolated in methanol fraction by preparative TLC method. M. minutum exhibited significant antioxidant activity with $\mathrm{IC}_{50}$ values of 54.3 and $168.9 \mu \mathrm{g} / \mathrm{mL}$, respectively [107]. The identification of hydramicromelinin in the active fractions was made based on detail spectral data as a potential lead of an antioxidant compound.

The potential antioxidant activity of methanol, hexane, ethyl acetate, and water extracts of $C$. indica fruits was evaluated. The results have showed that the highest total phenolic content was observed in the methanol extract [53]. Furthermore, methanol extract exhibited a remarkable antioxidant activity for DPPH and ABTS assays with the lowest $\mathrm{IC}_{50}$ values, 0.12 and $0.26 \mathrm{mg} / \mathrm{mL}$, respectively.

Most of the isolated antioxidant active components in plant extracts of various solvents have been identified; antioxidant activities are diverse. These differences might be due to the extraction of curry leaves in a single solvent instead of fractionating them into different solvents.
Furthermore, the various extraction methods and the extraction time and temperatures employed might have different levels and compositions of antioxidant compounds extracted, which further leads to the need for phytochemical characterization.

\section{Conclusion}

In recent years, the exponential growth of plants' use in medicine has been observed due to their remarkable pharmacological activities. The present review identified three of such important plants, M. koenigii, M. minutum, and $C$. indica, which have rich sources of bioactive metabolites. Their natural origin, low cost, and minimal adverse effects have attracted the scientific community to develop nutraceuticals and plant-based drugs. Clinical studies confirmed the pivotal role of M. koenigii and M. minutum in the prevention of various diseases. The amass quantity of information that has been accumulated in this regard has allowed us to understand the molecular mechanisms underlying these activities fully or partially in potential treatments. Although $C$. indica has been proven to be medicinally important, least or no attention was received by scientists. Therefore, further studies are essential for elucidating the role of the individual phytochemicals of $C$. indica in eliciting various pharmacological effects. The pharmacological effects of these three species differ on the part of the plant or fruit used. Furthermore, the geographical, seasonal, and other variations among countries and regions also influence the chemical composition. In closing, M. koenigii, $M$. minutum, and $C$. indica have proven to be promising candidates in both the drug designing by natural sources and the development of nutraceuticals. We believe that the current review provides a cumulation of information that will shed light innovatively for future investigation on the use of underutilized plant materials to discover new drugs with the aid of animal models and clinical trials.

\section{Data Availability}

All the data used to support the findings of this study are available from the corresponding author upon request.

\section{Conflicts of Interest}

The authors have declared no conflicts of interest. 


\section{Acknowledgments}

This work was supported by the National Research Council of Sri Lanka under ID Grant 18-063.

\section{Supplementary Materials}

Table S1: phytochemicals extracted from Murraya koenigii. Table S2: phytochemicals extracted from Micromelum minutum. Table S3: phytochemicals extracted from Clausena indica. (Supplementary Materials)

\section{References}

[1] A. G. Atanasov, B. Waltenberger, E.-M. Pferschy-Wenzig et al., "Discovery and resupply of pharmacologically active plant-derived natural products: a review," Biotechnology Advances, vol. 33, no. 8, pp. 1582-1614, 2015.

[2] H. Yuan, Q. Ma, L. Ye, and G. Piao, "The traditional medicine and modern medicine from natural products," Molecules, vol. 21, no. 5, p. 559, 2016.

[3] N. Thomford, D. Senthebane, A. Rowe et al., "Natural products for drug discovery in the 21st century: innovations for novel drug discovery," International Journal of Molecular Sciences, vol. 19, no. 6, p. 1578, 2018.

[4] D. J. Newman and G. M. Cragg, "Natural products as sources of new drugs over the nearly four decades from 01/1981 to 09/2019," Journal of Natural Products, vol. 83, no. 3, pp. 770-803, 2020.

[5] J. Hu, J. Wang, Q.-X. Gan et al., "Impact of red yeast rice on metabolic diseases: a review of possible mechanisms of action," Journal of Agricultural and Food Chemistry, vol. 68, no. 39, pp. 10441-10455, 2020.

[6] The Editors of Encyclopaedia, Encyclopaedia Britannica, Encyclopaedia Britannica Inc., Chicago, IL, USA, 2010.

[7] S. K. Samanta, R. Kandimalla, B. Gogoi et al., "Phytochemical portfolio and anticancer activity of Murraya koenigii and its primary active component, mahanine," Pharmacological Research, vol. 129, pp. 227-236, 2018.

[8] S. C. Saini, M. K. Tyagi, D. Amroha, and P. C. No, "Studies about murraya koenigii (quality estimation and antibacterial and antifungal properties)," International Journal of Pharmaceutical Science Invention, vol. 4, pp. 19-24, 2015.

[9] P. Dahiya, D. Gg, and S. Jakhar, "Murraya koenigii (L.) spreng: an ethnobotanical, phytochemical and pharmacological review," Journal of Pharmacognosy and Phytochemistry, vol. 3, pp. 109-119, 2014.

[10] P. A. Paranagama and J. J. Gunasekera, "The efficacy of the essential oils of Sri Lankan Cinnamomum zeylanicum fruit and Micromelum minutum leaf against Callosobruchus maculatus (F.) (Coleoptera: bruchidae)," Journal of Essential Oil Research, vol. 23, no. 1, pp. 75-82, 2011.

[11] M. Rahmani, R. A. Susidarti, H. B. M. Ismail et al., "Coumarins from Malaysian micromelum minutum," Phytochemistry, vol. 64, no. 4, pp. 873-877, 2003.

[12] A. Itharat, P. J. Houghton, E. Eno-Amooquaye, P. J. Burke, J. H. Sampson, and A. Raman, "In vitro cytotoxic activity of Thai medicinal plants used traditionally to treat cancer," Journal of Ethnopharmacology, vol. 90, no. 1, pp. 33-38, 2004.

[13] K. Koriem, M. Aminuddin, A. Kader, and N. Sheikh, "Antihyperglycemic, antihyperlipidemic and antiapoptotic activities of micromelum minutum seeds in diabetic rats," Journal of Molecular and Genetic Medicine, vol. 2013, pp. 1-8, 2013.
[14] J. A. John, S. R. R. Kurup, N. S. Pradeep, and B. Sabulal, "Chemical composition and antibacterial activity of the leaf oil of Clausena indica from South India," Journal of Essential Oil Bearing Plants, vol. 14, no. 6, pp. 776-781, 2011.

[15] P. T. Diep, A. M. Pawlowska, P. L. Cioni, C. V. Minh, L. M. Huong, and A. Braca, "Chemical composition and antimicrobial activity of Clausena indica (dalz) oliv. (Rutaceae) essential oil from Vietnam," Natural Product Communications, vol. 4, no. 6, pp. 869-872, 2009.

[16] S. C. Saini, G. Bala, and S. Reddy, "A review on curry leaves (murraya koenigii): versatile multi-potential medicinal plant," American Journal of Phytomedicine and Clinical Therapeutics, vol. 3, pp. 363-368, 2015.

[17] W. Reuther, L. D. Batchelor, and H. J. Webber, The Citrus Industry, University of California Press, Berkeley, CA, USA, 1967.

[18] M. H. Sohrab, R. Chowdhury, C. M. Hasan, and M. A. Rashid, "Chemotaxonomic significance of polyoxygenated flavonoids from the leaves of Micromelum minutum," Biochemical Systematics and Ecology, vol. 32, no. 9, pp. 829-831, 2004.

[19] T. H. Thai, O. Bazzali, T. M. Hoi et al., "Chemical composition of the essential oils from Vietnamese Clausena indica and C. Anisum-olens," Natural Products Communications, vol. 9, pp. 1531-1534, 2014.

[20] R. S. Ramsewak, M. G. Nair, G. M. Strasburg, D. L. DeWitt, and J. L. Nitiss, "Biologically active carbazole alkaloids from Murraya koenigii," Journal of Agricultural and Food Chemistry, vol. 47, no. 2, pp. 444-447, 1999.

[21] V. Jain, M. Momin, and K. Laddha, "Murraya koenigii: an updated review," International Journal of Ayurvedic and Herbal Medicine, vol. 2, pp. 607-627, 2012.

[22] C. Saha and B. K. Chowdhury, "Carbazoloquinones from murraya koenigii," Phytochemistry, vol. 48, no. 2, pp. 363-366, 1998.

[23] M. Fiebig, J. M. Pezzuto, D. D. Soejarto, and A. D. Kinghorn, "Koenoline, a further cytotoxic carbazole alkaloid from Murraya koenigii," Phytochemistry, vol. 24, no. 12, pp. 3041-3043, 1985.

[24] Y. Tachibana, H. Kikuzaki, N. H. Lajis, and N. Nakatani, "Comparison of antioxidative properties of carbazole alkaloids from Murraya koenigii leaves," Journal of Agricultural and Food Chemistry, vol. 51, no. 22, pp. 6461-6467, 2003.

[25] M. P. Rajendran, B. B. Pallaiyan, and N. Selvaraj, "Chemical composition, antibacterial and antioxidant profile of essential oil from Murraya koenigii (L.) leaves," International Journal of Pharmacy and Pharmaceutical Sciences, vol. 4, pp. 200-214, 2014.

[26] A. Ghasemzadeh, H. Z. E. Jaafar, A. Rahmat, and T. Devarajan, "Evaluation of bioactive compounds, pharmaceutical quality, and anticancer activity of curry leaf (murraya koenigii L.)," Evidence-Based Complementary and Alternative Medicine, vol. 2014, Article ID 873803, 8 pages, 2014.

[27] A. Sakunpak, K. Matsunami, H. Otsuka et al., "Isolation of new monoterpene coumarins from Micromelum minutum leaves and their cytotoxic activity against leishmania major and cancer cells," Food Chemistry, vol. 139, no. 1-4, pp. 458-463, 2013.

[28] R. Lekphrom, K. Kanokmedhakul, W. Sangsopha, and S. Kanokmedhakul, "A new coumarin from the roots of Micromelum minutum," Natural Product Research, vol. 30, no. 21, pp. 2383-2388, 2016. 
[29] R. Lekphrom, S. Kanokmedhakul, V. Kukongviriyapan, and K. Kanokmedhakul, "C-7 oxygenated coumarins from the fruits of micromelum minutum," Archives of Pharmacal Research, vol. 34, no. 4, pp. 527-531, 2011.

[30] N. Kamkaen and N. Ruangrangsi, "Chemical compositions and antimicrobial activities of essential oils from Micromelum minutum," Thailand Journal of Health Research, vol. 17, pp. 148-153, 2003.

[31] H. D. Trung, T. D. Thang, P. H. Ban, T. M. Hoi, D. N. Dai, and I. A. Ogunwande, "Terpene constituents of the leaves of five Vietnamese species of Clausena (Rutaceae)," Natural Product Research, vol. 28, pp. 622-630, 2014.

[32] Y. Tachibana, H. Kikuzaki, N. H. Lajis, and N. Nakatani, "Antioxidative activity of carbazoles from murraya koenigii leaves," Journal of Agricultural and Food Chemistry, vol. 49, no. 11, pp. 5589-5594, 2001.

[33] P. Akula, A. N. Sree, B. Santosh, and B. Sandeep, "Evaluation of anti-microbial activity of leaf and bark extracts of Murraya koenigii (curry leaves)," Journal of Pharmacognosy and Phytochemistry, vol. 5, pp. 101-105, 2016.

[34] K. Nakahara, G. Trakoontivakorn, N. S. Alzoreky, H. Ono, M. Onishi-Kameyama, and M. Yoshida, "Antimutagenicity of some edible Thai plants, and a bioactive carbazole alkaloid, mahanine, isolated from Micromelum minutum," Journal of Agricultural and Food Chemistry, vol. 50, no. 17, pp. 47964802, 2002.

[35] F.-T. Zohora, C. Mahmood Hasan, and M. Ahsan, "Chemical constituents, cytotoxic activities and traditional uses of Micromelum minutum (Rutaceae): a review," Pharmacy \& Pharmacology International Journal, vol. 7, no. 5, pp. 229236, 2019.

[36] P. Balakumar, K. Maung-U, and G. Jagadeesh, "Prevalence and prevention of cardiovascular disease and diabetes mellitus," Pharmacological Research, vol. 113, pp. 600-609, 2016.

[37] S. Paul, T. K. Bandyopadhyay, and A. Bhattacharyya, "Immunomodulatory effect of leaf extract of Murraya koenigiiin diabetic mice," Immunopharmacology and Immunotoxicology, vol. 33, no. 4, pp. 691-699, 2011.

[38] H. A. Lawal, M. K. Atiku, D. G. Khelpai, and N. N. Wannang, "Hypoglycaemic and hypolipidaemic effect of aqueous leaf extract of Murraya koenigii in normal and alloxan-diabetic rats," Nigerian Journal of Physiological Sciences, vol. 23, pp. 37-40, 2008.

[39] A. N. Kesari, S. Kesari, S. K. Singh, R. K. Gupta, and G. Watal, "Studies on the glycemic and lipidemic effect of Murraya koenigii in experimental animals," Journal of Ethnopharmacology, vol. 112, no. 2, pp. 305-311, 2007.

[40] P. Arulselvan and S. P. Subramanian, "Beneficial effects of Murraya koenigii leaves on antioxidant defense system and ultra structural changes of pancreatic $\beta$-cells in experimental diabetes in rats," Chemico-Biological Interactions, vol. 165, no. 2, pp. 155-164, 2007.

[41] U. N. Kamakshi, D. S. Rao, K. Y. Suvarchala, K. Anusha, and B. V. Rao, "Comparative hypoglycemic study of aloe vera, Murraya koenigii and Azadirachta indica," International Journal of Pharmacognosy and Phytochemical Research, vol. 7, pp. 923-927, 2015.

[42] M. K. Vinuthan, V. Girish Kumar, J. P. Ravindra, and K. Narayana, "Effect of extracts of Murraya koenigii leaves on the levels of blood glucose and plasma insulin in alloxaninduced diabetic rats," Indian Journal of Physiology and Pharmacology, vol. 48, pp. 348-352, 2004.
[43] S. Yadav, V. Vats, Y. Dhunnoo, and J. K. Grover, "Hypoglycemic and antihyperglycemic activity of Murraya koenigii leaves in diabetic rats," Journal of Ethnopharmacology, vol. 82, no. 2-3, pp. 111-116, 2002.

[44] S. James, E. Omwirhiren, I. Joshua, I. Suleiman, and J. Endas, "In vitro and in vivo assessment of the anti-diabetes potentials of murraya koenigii, Hibiscus cannabinus, vernonia amydalina and telfairia occidentalis leave extract," International Journal of Biochemistry Research \& Review, vol. 15, no. 1, pp. 1-11, 2016.

[45] M. Bhat and B. Joshi, "Islet protective and insulin secretion property of Murraya koenigii and Ocimum tenuflorum in streptozotocin-induced diabetic mice," Canadian Journal of Physiology and Pharmacology, vol. 90, pp. 371-378, 2012.

[46] M. Incani, F. Sentinelli, L. Perra et al., "Glycated hemoglobin for the diagnosis of diabetes and prediabetes: diagnostic impact on obese and lean subjects, and phenotypic characterization," Journal of Diabetes Investigation, vol. 6, no. 1, pp. 44-50, 2015.

[47] E. Akubugwo, "Effect of plant spices (thymus vulgaris, murraya koenigii, ocimum gratissimum, piper guineense) on hemoglobin glycation, selected enzymes and red blood cell indices in alloxan-induced diabetic rats," International Journal of Biochemistry Research \& Review, vol. 4, no. 5, pp. 358-366, 2014.

[48] D. Wijetunge and K. Perera, "A novel in vitro method to identify protein glycation inhibitors," Asian Journal of Medical Sciences, vol. 5, pp. 15-21, 2014.

[49] S. V. Tembhurne and D. M. Sakarkar, "Influence of Murraya koenigii on experimental model of diabetes and progression of neuropathic pain," Research in Pharmaceutical Sciences, vol. 5, pp. 41-47, 2010.

[50] U. M. Iyer and U. V. Mani, "Studies on the effect of curry leaves supplementation (Murraya koenigi) on lipid profile, glycated proteins and amino acids in non-insulin-dependent diabetic patients," Plant Foods for Human Nutrition, vol. 40, no. 4, pp. 275-282, 1990.

[51] O. P. S. Patel, A. Mishra, R. Maurya et al., "Naturally occurring carbazole alkaloids from murraya koenigii as potential antidiabetic agents," Journal of Natural Products, vol. 79, no. 5, pp. 1276-1284, 2016.

[52] N. V. Quan, T. D. Xuan, L. H. Anh, and Tran, "Bio-guided isolation of prospective bioactive constituents from roots of Clausena indica (Dalzell) oliv,” Molecules, vol. 24, no. 24, p. $4442,2019$.

[53] A. La, T. Dang Xuan, N. Thuy, N. Quan, and L. Trang, "Antioxidant and a-amylase inhibitory activities and phytocompounds of Clausena indica fruits," Medicines, vol. 7, p. 10, 2020.

[54] H. Li, Y. Yao, and L. Li, "Coumarins as potential antidiabetic agents," Journal of Pharmacy and Pharmacology, vol. 69, no. 10, pp. 1253-1264, 2017.

[55] J. Naowaboot, N. Somparn, S. Saentaweesuk, and P. Pannangpetch, "Umbelliferone improves an impaired glucose and lipid metabolism in high-fat diet/streptozotocininduced type 2 diabetic rats," Phytotherapy Research, vol. 29, no. 9, pp. 1388-1395, 2015.

[56] H.-J. Liang, F.-M. Suk, C.-K. Wang et al., "Osthole, a potential antidiabetic agent, alleviates hyperglycemia in $\mathrm{db} / \mathrm{db}$ mice," Chemico-Biological Interactions, vol. 181, no. 3, pp. 309-315, 2009.

[57] B. Ramesh and K. V. Pugalendi, "Antioxidant role of umbelliferone in STZ-diabetic rats," Life Sciences, vol. 79, no. 3, pp. 306-310, 2006. 
[58] L. Eaton, "World cancer rates set to double by 2020," BMJ, vol. 326, p. 728, 2003.

[59] A. Ismail, B. Noolu, R. Gogulothu, S. Perugu, A. Rajanna, and S. K. Babu, "Cytotoxicity and proteasome inhibition by alkaloid extract from murraya koenigii leaves in breast cancer cells-molecular docking studies," Journal of Medicinal Food, vol. 19, no. 12, pp. 1155-1165, 2016.

[60] K. S. Amin, S. Jagadeesh, G. Baishya et al., "A naturally derived small molecule disrupts ligand-dependent and ligand-independent androgen receptor signaling in human prostate cancer cells," Molecular Cancer Therapeutics, vol. 13, no. 2, pp. 341-352, 2014.

[61] R. Das, K. Bhattacharya, S. K. Samanta, B. C. Pal, and C. Mandal, "Improved chemosensitivity in cervical cancer to cisplatin: synergistic activity of mahanine through STAT3 inhibition," Cancer Letters, vol. 351, pp. 81-90, 2014.

[62] M. K. Roy, V. N. Thalang, G. Trakoontivakorn, and K. Nakahara, "Mahanine, a carbazole alkaloid from Micromelum minutum, inhibits cell growth and induces apoptosis in U937 cells through a mitochondrial dependent pathway," British Journal of Pharmacology, vol. 145, no. 2, pp. 145-155, 2005.

[63] K. W. Yip and J. C. Reed, "Bcl-2 family proteins and cancer," Oncogene, vol. 27, no. 50, pp. 6398-6406, 2008.

[64] V. Iman, S. Mohan, S. Abdelwahab et al., "Anticancer and anti-inflammatory activities of girinimbine isolated from Murraya koenigii," Drug Design, Development and Therapy, vol. 11, pp. 103-121, 2016.

[65] S. Mohan, S. I. Abdelwahab, S. C. Cheah, M. S. Sukari, N. Shamsuddin, and M. R. Mustafa, "Apoptosis effect of girinimbine isolated from Murraya koenigii on lung cancer cells, in vitro," Evidence-Based Complementary and Alternative Medicine, vol. 2013, Article ID 689865, 12 pages, 2013.

[66] V. Iman, H. Karimian, S. Mohan et al., "In vitro and in vivo anti-angiogenic activity of girinimbine isolated from Murraya koenigii," Drug Design, Development and Therapy, vol. 9, pp. 1281-1292, 2015.

[67] S. Syam, A. B. Abdul, M. A. Sukari, S. Mohan, S. I. Abdelwahab, and T. S. Wah, "The growth suppressing effects of girinimbine on HepG2 involve induction of apoptosis and cell cycle arrest," Molecules, vol. 16, no. 8, pp. 7155-7170, 2011.

[68] F. Ahmadipour, M. I. Noordin, S. Mohan et al., "Koenimbin, a natural dietary compound of murraya koenigii (L) spreng: inhibition of MCF7 breast cancer cells and targeting of derived MCF7 breast cancer stem cells (CD44+/CD24-/low): an in vitro study," Drug Design, Development and Therapy, vol. 9, pp. 1193-1208, 2015.

[69] B. Kamalidehghan, S. Ghafouri-Fard, E. Motevaseli, and F. Ahmadipour, "Inhibition of human prostate cancer (PC3) cells and targeting of PC-3-derived prostate cancer stem cells with koenimbin, a natural dietary compound from Murraya koenigii (L) spreng," Drug Design, Development and Therapy, vol. 12, pp. 1119-1133, 2018.

[70] S. K. Yeap, N. Abu, N. E. Mohamad et al., "Chemopreventive and immunomodulatory effects of Murraya koenigii aqueous extract on $4 \mathrm{~T} 1$ breast cancer cell-challenged mice," BMC Complementary and Alternative Medicine, vol. 15, p. 306, 2015.

[71] WHO, Cardiovascular Diseases (CVDs), WHO, Geneva, Switzerland, 2021, https://www.who.int/news-room/factsheets/detail/cardiovascular-diseases-(cvds).

[72] S. Leelama, B. A. Khan, and A. Abraham, "Biological response in rats to the addition of Murraya Koenigii and
Brassica juncea to the diet," Plant Foods for Human Nutrition, vol. 49, pp. 294-299, 1996.

[73] J.-T. Xie, W.-T. Chang, C.-Z. Wang et al., "Curry leaf (murraya koenigii spreng) reduces blood cholesterol and glucose levels in ob/ob mice," The American Journal of Chinese Medicine, vol. 34, no. 2, pp. 279-284, 2006.

[74] A. Butt, N. Waris, K. Baqa et al., "Comparative effect of beta blocker-atenolol and Murraya koenigii (L.) spreng (curry leaves) on cardiac enzyme (CK-MB) level in male albino rats," Pakistan Journal of Pharmaceutical Sciences, vol. 32, pp. 1643-1648, 2019.

[75] D. Gupta, M. Kumar, and V. Gupta, "An in vitro investigation of antimicrobial efficacy of Euphorbia Hirta and Murraya koenigii against selected pathogenic microorganisms," Asian Journal of Pharmaceutical and Clinical Research, vol. 11, no. 5, pp. 359-363, 2018.

[76] B. A. Nancy, K. Elumalai, P. Sivamani, C. Kandeepan, and R. V. Kalaimathi, "Screening of Bacteria from selected marketed fishes and their sensitivity spectrum to extracts of spicy indigenous plants," International Journal of Current Research and Academic Review, vol. 2, pp. 281-293, 2004.

[77] R. J. Kumar, "Antifungal potential of some medicinal plants against seed-borne fungi," International Research Journal of Science and Engineering, vol. 3, pp. 28-32, 2015.

[78] H. K. Singh, A. A. Charan, A. I. Charan, and S. M. Prasad, "Antifungal and antibacterial activity of methanolic, ethanolic and acetonic leaf extracts of curry leaves (Murraya koenigii)," Journal of Pharmacognosy and Phytochemistry, vol. 6, pp. 1797-1802, 2017.

[79] S. Rajnikant, A. Kumar, and A. Chattree, "Antioxidant and antifungal potential of murraya koenigii leaves extracts (crude) and essential oil," Chemical Science Transactions, vol. 4, pp. 5-9, 2015.

[80] R. Rautela, G. K. Das, S. Prasad et al., "In-vitro antibacterial potential of aqueous and ethanolic extract of Aegle marmelos and Murraya koenigii leaf on the bacterial strains isolated from endometritic cows," Indian Journal of Animal Sciences, vol. 87, pp. 844-845, 2017.

[81] N. H. Abu Bakar, A. Bakar, M. Sukari, M. Rahmani, K. Khalid, and U. Yusuf, "Chemical constituents from stem barks and roots of Murraya koenigii (rutaceae), Malaysian," Journal of Analytical Science, vol. 11, 2007.

[82] M. A. L. G. Taguiling, "Phytochemical screening and antibacterial activity of mircromelum minutum," International Journal of Green and Herbal Chemistry, vol. 5, pp. 171-179, 2016.

[83] J. J. Brophy, P. I. Forster, and R. J. Goldsack, "Leaf oils of the Australian species of Clausena and micromelum (rutaceae)," Journal of Essential Oil Research, vol. 28, no. 5, pp. 406-412, 2016.

[84] W. F. Li, L. Y. Zhen, and H. Qiu-Chan, "Study on antimicrobial effect of the flavonoids in Clausena indica (datz). Oliv. fruits," Journal of Anhui Agricultural Sciences, vol. 26, pp. 255-261, 2011.

[85] S. Jakhar, D. Gahlawat, S. Dahiya, U. Swami, M. Verma, and P. Dahiya, "Antibacterial and antioxidant potential of leaf and seed extracts of murraya koenigii (linn.) spreng," British Microbiology Research Journal, vol. 10, no. 6, pp. 1-7, 2015.

[86] R. M. Bhuva and Y. M. Dixit, "Comparative antimicrobial activities of neem and curry leaf extracts and their synergistic effect against selected pathogenic bacteria and fungus," International Research Journal of Pharmacy, vol. 6, no. 11, pp. 755-759, 2015. 
[87] N. Gaurav, "Phytochemical analysis and antibacterial activity of different leaf extracts of murraya koenigii," International Journal of Biochemistry \& Cell Biology, vol. 2, no. 2, pp. 1-5, 2016.

[88] P. Rajeshwari and K. A. Raveesha, "Antimicrobial potential of selected plant extracts against important plant pathogenic microorganisms," International Journal of Pharma Bio Sciences, vol. 8, pp. 65-70, 2017.

[89] A. Saleem, U. Younas, G. Muhammad et al., "Phytochemicals screening by ftir spectroscopy and antimicrobial activity of different solvent fractions from murraya koenigii L. shoots," International Research Journal of Pharmacy, vol. 7, no. 4, pp. 30-37, 2016.

[90] M. Mohan, S. Z. Haider, A. Sharma, R. Seth, and M. Sharma, "Antimicrobial activity and composition of the volatiles of cinnamomum tamala nees. And murraya koenigii (L.) spreng from Uttarakhand (India)," Asian Pacific Journal of Tropical Disease, vol. 2, pp. S324-S327, 2012.

[91] S. Imran, "Studies on the antibacterial peptide isolated from Murrya koenigii leaves," Research Journal of Biotechnology, vol. 8, pp. 49-53, 2013.

[92] C. Baskaran, V. Ratha Bai, and D. Kanimozhi, "Screening for antimicrobial activity and phytochemical analysis of various leaf extract of Murraya koenigii," International Journal of Research in Ayurveda and Pharmacy, vol. 2, pp. 1807-1810, 2011.

[93] M. Panghal, V. Kaushal, and J. P. Yadav, "In vitro antimicrobial activity of ten medicinal plants against clinical isolates of oral cancer cases," Annals of Clinical Microbiology and Antimicrobials, vol. 10, no. 1, p. 21, 2011.

[94] S. Chanda and R. Dave, "In vitro models for antioxidant activity evaluation and some medicinal plants possessing antioxidant properties: an overview," African Journal of Microbiology Research, vol. 3, pp. 981-996, 2009.

[95] D. J. Charles, Antioxidant Properties of Spices, Herbs and Other Sources, Springer Science \& Business Media, Berlin, Germany, 2012.

[96] H. P. Witschi, "Enhancement of tumor formation in mouse lung by dietary butylated hydroxytoluene," Toxicology, vol. 21, no. 2, pp. 95-104, 1981.

[97] E. M. Atta, N. H. Mohamed, and A. A. M. Abdelgawad, "Antioxidants: an overview on the natural and synthetic types," European Chemical Bulletin, vol. 6, no. 8, p. 365, 2017.

[98] R. Balakrishnan, D. Vijayraja, S.-H. Jo, P. Ganesan, I. SuKim, and D.-K. Choi, "Medicinal profile, phytochemistry, and pharmacological activities of murraya koenigii and its primary bioactive compounds," Antioxidants, vol. 9, no. 2, p. 101, 2020.

[99] A. K. Das, V. Rajkumar, and D. K. Dwivedi, "Antioxidant effect of curry leaf (Murraya koenigii) powder on quality of ground and cooked goat meat," International Food Research Journal, vol. 18, pp. 563-569, 2011.

[100] D. T. Abeysinghe, K. A. H. Kumara, K. A. D. Kaushalya, U. G. Chandrika, and D. D. D. H. Alwis, "Phytochemical screening, total polyphenol, flavonoid content, in vitro antioxidant and antibacterial activities of Sri Lankan varieties of Murraya koenigii and Micromelum minutum leaves," Heliyon, vol. 7, no. 7, Article ID e07449, 2021.

[101] P. Gupta, A. Nahata, and V. K. Dixit, "An update on Murraya koenigii spreng: a multifunctional ayurvedic herb," Journal of Chinese Integrative Medicine, vol. 9, pp. 824-833, 2011.

[102] M. B. Ningappa, R. Dinesha, and L. Srinivas, "Antioxidant and free radical scavenging activities of polyphenol-enriched curry leaf (Murraya koenigii L.) extracts," Food Chemistry, vol. 106 , no. 2 , pp. $720-728,2008$.

[103] V. Sablania, S. J. D. Bosco, and M. Bashir, "Extraction process optimization of Murraya koenigii leaf extracts and antioxidant properties," Journal of Food Science and Technology, vol. 56, no. 12, pp. 5500-5508, 2019.

[104] R. S. Tomar, S. Banerjee, and S. Kaushik, "Assessment of antioxidant activity of leaves of Murraya koenigii extracts and it's comparative efficacy analysis in different solvents," Journal of Pharmaceutical Sciences and Research, vol. 9, pp. 288-291, 2017.

[105] M. Zahin, F. Aqil, F. M. Husain, and I. Ahmad, "Antioxidant capacity and antimutagenic potential of murraya koenigii," BioMed Research International, vol. 2013, Article ID 263509, 10 pages, 2013.

[106] S. Gupta and J. Prakash, "Studies on Indian green leafy vegetables for their antioxidant activity," Plant Foods for Human Nutrition, vol. 64, no. 1, pp. 39-45, 2009.

[107] K. Kassim, L. Cee, I. Amin, and K. Awang, "Isolation of antioxidative compounds from Micromelum minutum guided by preparative thin layer chromatography-2,2Diphenyl-1-picrylhydrazyl (PTLC-DPPH) bioautography method," Food Chemistry, vol. 272, 2018. 